\title{
Self-Humidifying Proton Exchange Membranes for Fuel Cell Applications: Advances and Challenges
}

\author{
Seyed Hesam Mirfarsi ${ }^{1,2}$, Mohammad Javad Parnian ${ }^{1,3, *}$ and Soosan Rowshanzamir ${ }^{1,2,4}$ \\ 1 School of Chemical Engineering, Iran University of Science and Technology, Narmak, \\ Tehran 16846-13114, Iran; Hesam_mirfarsi@yahoo.com (S.H.M.); Rowshanzamir@iust.ac.ir (S.R.) \\ 2 Fuel Cell Laboratory, Green Research Center, Iran University of Science and Technology, Narmak, \\ Tehran 16846-13114, Iran \\ 3 Department of Chemistry, University of Calgary, 2500 University Drive NW, Calgary, AB T2N 1N4, Canada \\ 4 Center of Excellence for Membrane Science and Technology, Iran University of Science \& Technology Narmak, \\ Tehran 16846-13114, Iran \\ * Correspondence: Mohammadjavad.parnia@ucalgary.ca
}

Received: 4 August 2020; Accepted: 26 August 2020; Published: 1 September 2020

check for updates

\begin{abstract}
Polymer electrolyte fuel cells (PEFCs) provide efficient and carbon-free power by converting the hydrogen chemical energy. The PEFCs can reach their greatest performance in humidified condition, as proton exchange membranes (PEMs) should be humidified for their proton transportation function. Thus, external humidifiers are commonly employed to increase the water content of reactants. However, being burdened with external humidifiers can make the control of PEFCs complicated and costly, in particular for transportation application. To overcome this issue, self-humidifying PEMs have been introduced, with which PEFC can be fed by dry reactants. In fact, internal humidification is accomplished by produced water from the recombination of permeated hydrogen and oxygen gases on the incorporated platinum catalysts within the PEM. While the water production agent remains constant, there is a broad range of additives that are utilized to retain the generated water and facilitate the proton conduction path in the PEM. This review paper has classified the aforementioned additives in three categories: inorganic materials, proton-conductive materials, and carbon-based additives. Moreover, synthesis methods, preparation procedures, and characterization tests are overviewed. Eventually, self-humidifying PEMs endowed with platinum and different additives are compared from performance and stability perspectives, such as water uptake, proton conductivity, fuel cell performance, gas cross-over, and the overall durability. In addition, their challenges and possible solutions are reviewed. Considering the concerns regarding the long-term durability of such PEMs, it seems that further investigations can be beneficial to confirm their reliability for prolonged PEFC operation.
\end{abstract}

Keywords: polymer electrolyte fuel cells; proton exchange membranes; self-humidifying membranes; nanocomposite membranes; ultra-thin membranes; gas cross-over

\section{Introduction}

Even though the transition to renewable energies has not yet been achieved [1], it is fortunate that measures are increasingly being taken to tackle environmental problems caused by the conventional combustion of fossil fuels [2,3]. Having the potential to reduce energy consumption and air pollution has made polymer electrolyte fuel cells (PEFCs) worthy of further development and commercialization [4]. PEFCs provide efficient, clean, and noise-free power for a wide range of applications from transportation to stationary and portable devices, through the conversion of hydrogen chemical energy to electricity $[5,6]$. In particular, PEFCs are perfectly suitable for transportation usage on account of their relatively high power density $[7,8]$. 
As illustrated in Figure 1a, a single cell in PEFCs consists of bipolar plates and membrane-electrode assembly (MEA). The uniform distribution of reactants (hydrogen and air/oxygen) over the MEA active surface, heat removal, and current (electrons) transfer from each cell are the main functions of bipolar plates [9]. MEA, on the other hand, is the principal component in PEFCs, in which the proton exchange membrane (PEM) is sandwiched between anode and cathode electrodes. Each electrode consists of a gas diffusion layer (GDL) and catalyst layer (CL), where electrochemical reactions occur according to Equations (1) and (2) [7]. In practice, several cells are being stacked to provide the required output voltage. Although the complete reaction in the PEFC is presented in Equation (3), the direct combination of $\mathrm{H}_{2}$ and $\mathrm{O}_{2}$ on the catalyst surface merely leads to heat and water production, according to Equation (4) [10].

$$
\begin{gathered}
\mathrm{H}_{2} \rightarrow 2 \mathrm{H}^{+}+2 e^{-} \text {(Anode side) } \\
1 / 2 \mathrm{O}_{2}+2 \mathrm{H}^{+}+2 e^{-} \rightarrow \mathrm{H}_{2} \mathrm{O} \text { (Cathode side) } \\
\mathrm{H}_{2}+1 / 2 \mathrm{O}_{2} \rightarrow \mathrm{H}_{2} \mathrm{O}+\text { electricity (Complete fuel cell reaction) } \\
\mathrm{H}_{2}+1 / 2 \mathrm{O}_{2} \rightarrow \mathrm{H}_{2} \mathrm{O}+\text { heat (Direct combination of reactants on the catalyst surface) }
\end{gathered}
$$

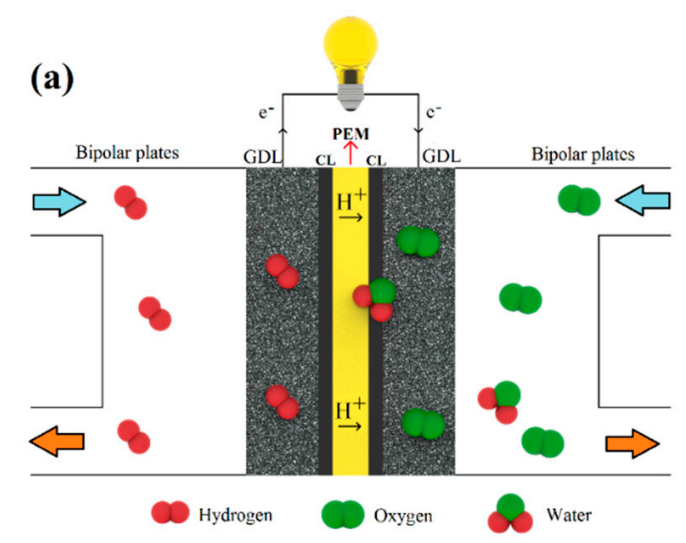

(b)

Nafion

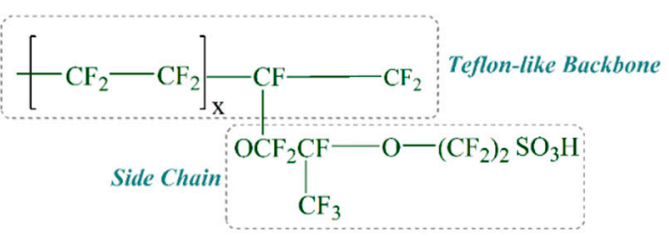

(c)

\section{SPEEK}<smiles>Cc1ccc(C(=O)c2ccc(Oc3ccc(OC(C)(C)C)cc3S(=O)(=O)O)cc2)cc1</smiles>

Figure 1. (a) Schematic illustration of polymer electrolyte fuel cells (PEFCs) and chemical structure of (b) Nafion and (c) sulfonated poly(ether ether ketone) (SPEEK) proton exchange membranes (PEMs).

In comparison with other components in the MEA, PEMs are of prime concern and play a vital role from performance and durability improvement to cost reduction [11]. PEMs should exhibit high proton conductivity from anode side to the cathode side. By contrast, they should not display considerable gaseous reactants cross-over to the opposite side, nor allow the passage of electrons [7,12,13]. In addition, in terms of stability, these membranes undergo chemical degradation as well as mechanical stresses 
during fuel cell operation. Free radicals' attack to the polymeric structure of membranes leads to chemical degradation and the formation of pinholes [14-16]. These radicals are generated by the cross-over of hydrogen to the cathode side, oxygen to the anode side, and also an incomplete oxygen reduction reaction. In addition, mechanical factors, e.g., fatigue $[17,18]$ and assembly-induced stresses [19] might result in the sudden failure of the PEMs. Currently, perfluorosulfonic acid (PFSA) membranes such as Nafion (Figure 1b) have widely been used for electrochemical energy devices, including PEFCs [20-23]. However, prohibitive cost and durability issues have hindered PEFCs from penetrating the market competitively [24,25]. Thus, alternative PEMs are sought after in order to fulfill the aforementioned requirements as much as possible, and it can be said that the hydrocarbon-based PEMs, e.g., sulfonated poly(ether ether ketone) (SPEEK) [26,27], with chemical structure according to Figure 1c, have shown promising characteristics for prolonged PEFC operation. As shown in Figure 1c, $n$ indicates the number of PEEK units with a sulfonic acid group attached upon them. Furthermore, different approaches such as thermal cross-linking [28] and nanocomposite membranes [29-31] can be adopted to further improve the overall stability of SPEEK membranes.

In essence, PFSAs and hydrocarbon-based PEMs alike reach their maximum state of proton conduction and electrochemical performance once they are fully hydrated [32]. Hence, external humidification systems are mainly used to maintain a sufficient level of hydration in the polymeric membranes by humidifying inlet gases. However, humidifier malfunction might lead to membrane dehydration or "flooding" phenomena; in either case, the overall performance of the PEFC will be dramatically declined [33]. To prevent these issues, three measures have frequently been taken. First of all, bipolar or hybrid fuel cells have received tremendous attention since they were developed [34-36]. Bipolar membrane fuel cells employ a two-layer composite membrane that comprises a PEM at the anode side and an anion exchange membrane (AEM) at the cathode side. In this system, $\mathrm{H}^{+}$and $\mathrm{OH}^{-}$ions migrate toward the PEM/AEM junction, and water molecules will be produced once they are recombined [34]. As reported in other literature, bipolar membranes are promising materials by nature, and their current output power densities at dry condition are $0.327 \mathrm{~W} \mathrm{~cm}^{-2}$ at $50{ }^{\circ} \mathrm{C}$ for Nafion/quaternary ammonium polysulfone (QAPS) bipolar membrane [35] and $0.067 \mathrm{~W} \mathrm{~cm}^{-2}$ at $80^{\circ} \mathrm{C}$ for a sulfonated poly (1,4-phenylene ether-ether-sulfone) (SPEES)/quaternized polysulfone (QPS) bipolar membrane [36], and they could be a reliable substitute for self-regulating miniature fuel cells. Secondly, some studies have focused on developing anhydrous membranes that promise acceptable performance at low humidification levels and high temperatures and can tolerate the fluctuation in operating conditions in prolonged fuel cell operation [37-39]. The most remarkable concept among them might be the "nanocrack-assisted" hydration inspired by the cactus plant [40]. Park et al. in this research deposited a thin hydrophobic layer on the membrane surface by means of plasma treatment. Similar to the way cactus retains water in arid conditions, the nano-sized cracks on the deposited hydrophobic layer can swell in humidified conditions or become narrower in anhydrous conditions in order to minimize the water loss. These nanocracks can act as nanovalves at low humidity levels and maintain an appropriate degree of hydration for the membrane. This approach showed promising fuel cell performance at $120{ }^{\circ} \mathrm{C}$ and $35 \%$ humidity [40].

However, external humidifiers have remained as a burden for fuel cell vehicles. To address this problem, the term "self-humidifying proton exchange membranes" was introduced, where the PEMs are endowed with Pt nanoparticles as internal water production catalytic sites together with other additives to retain hydration and improve proton conductivity. Thus, in these cases, external humidifiers were no longer needed [41]. This approach not only reduces the cost and complexity of PEFCs, but also increases their power density, as for the Toyota MIRAI fuel cell vehicle, the humidifier removal contributed to a $13 \mathrm{~kg}$ and $15 \mathrm{~L}$ reduction in weight and volume, respectively [42].

It should be noted that the self-humidification agent, which is a catalyst anchored upon a support, can be integrated either in catalyst layers [43-45] or membranes that will be addressed herein. The incorporation of self-humidifying agents into the catalyst layer can help retain produced water at dry operation to some extent; in particular, it is an attractive approach for ultra-thin PEMs. For the latter 
mode of self-humidification (self-humidifying PEMs), platinum catalyst particles are incorporated into the PEMs, enabling them to produce water within the PEM ensuing from the exothermic reaction of permeated hydrogen and oxygen gases through the membrane (Equation (4)). It is widely accepted that internal humidification takes place in three steps. The first and the most sluggish step is the permeation of reactants, whereas the other two steps are the adsorption and recombination of feed gases, respectively. In other words, self-humidifying PEMs channel their permeated gas into supplying water inside the membrane, rather than causing mixed potential at the cathode or radical-induced chemical degradation [46]. In addition to Pt incorporation, some other additives are commonly used as support or additives in self-humidifying PEMs to retain the produced water and increase the initial proton conductivity of membranes. These additives include inorganic materials for water retention (namely hygroscopic metal oxides, zeolites, and clays), highly proton-conductive materials such as heteropolyacids (HPAs) or functionalized fillers, and carbon-based additives, e.g., graphene oxide (GO). This paper aims to review the advances of self-humidifying PEMs as well as their prevailing challenges.

\section{Self-Humidifying PEMs Incorporated with Inorganic Additives}

In this section, a family of additives with outstanding water retention properties will be discussed. This category includes, but it is not limited to hygroscopic oxides, silica aerogel, zeolites, clays, and layered double hydroxides. Hygroscopic oxide is chosen as a representative in Figure 2a in order to demonstrate the function of this type of filler.

The concept of "self-humidifying PEMs" was first coined in 1996 by Watanabe et al. [41]. As schematically shown in Figure 2a, either silica or titania $(5-15 \mathrm{~nm})$ were added to the Nafion solution for water storage and usage under dry feed gases. Water retention is an intrinsic feature of $\mathrm{SiO}_{2}$ and $\mathrm{TiO}_{2}$ nanoparticles $[47,48]$. Subsequently, a solution of $\left[\mathrm{Pt}\left(\mathrm{NH}_{3}\right)_{4}\right] \mathrm{Cl}_{2}$ was used to deposit $\mathrm{Pt}$ nanoparticles (1-2 nm) into the cast PEMs by cation exchange treatment. Then, exchanged Pt cations were reduced, followed by membrane activation in the acid solution. Therefore, self-humidifying PEMs with a thickness of about $50 \mu \mathrm{m}$ were prepared [41]. The amount of incorporated Pt was found to be $0.07 \mathrm{mg} \mathrm{cm}^{-2}$, according to the inductively coupled plasma (ICP) spectrometry. A significant rise in the water uptake (WU) of self-humidifying membranes showcased their ability in water retention, where the WU of plain membranes soared from $16.9 \%$ to $37.9 \%$ and $41.2 \%$ for Pt-TiO $2 / \mathrm{PEM}$ and $\mathrm{Pt}-\mathrm{SiO}_{2} / \mathrm{PEM}$ nanocomposites, respectively.

Likewise, in another study by Hagihara et al. [49], hydrophilic clusters in Nafion PEMs were enlarged about $10 \%$ due to the addition of $\mathrm{SiO}_{2}$ nanoparticles. In dry conditions, plain Nafion and membranes incorporated solely with metal oxides illustrated high ohmic resistance (poor proton conductivity), whereas self-humidifying PEMs exhibited outstandingly low ohmic resistance (high proton conductivity) [41]. It is worth mentioning that self-humidifying PEM incorporated with smaller $\mathrm{TiO}_{2}$ particles $(5 \mathrm{~nm}$ ) and consequently a higher surface area exhibited a higher water sorption and lower ohmic resistance in comparison with the PEM incorporated with larger titania nanoparticles $(15 \mathrm{~nm})$. In addition, water production by oxygen reduction reaction at the cathode (as presented in Equation (2)), especially at high current densities, creates a water concentration gradient across the membrane, and water can diffuse back toward the anode side, as depicted in Figure 2a. Therefore, thin self-humidifying PEMs endowed with hygroscopic oxides hoarded the back-diffused water as well and showed even lower ohmic resistance at higher loads [41]. Moreover, consumed hydrogen for humidification purposes was found to be negligible (a few percent loss), assuming that the difference between permeated hydrogen to the cathode between additive-free and nanocomposite PEMs is solely attributed to the catalytic reaction within the PEM [41].

In another study, Watanabe et al. investigated the effect of current density on the regional ohmic resistance of self-humidifying and plain PEMs in more depth [53]. A recast Nafion 112 membrane (50 $\mu \mathrm{m}$ thick) exhibited high resistance near the anode catalyst layer, and it increased with an increment of current density. This behavior was attributed to the electro-osmotic drag in the PEMs, which is the dominating form of water transport near the anode and dries this region. As shown in 
Figure 2a, water molecules accompany protons toward the cathode side according to the "vehicular mechanism" theory [7]. However, near the cathode electrode, they observed significantly lower resistance, which was further reduced at higher current densities due to the water back-diffusion impact. Self-humidifying PEMs incorporated with $\mathrm{Pt}$ and $\mathrm{TiO}_{2}$, on the other hand, represented low ohmic resistance throughout the membrane thickness, even at high current densities. This feature could be promising, since the self-humidifying PEM demonstrated resilience at abrupt load changes. Equally important, plain membrane, $\mathrm{TiO}_{2} / \mathrm{PEM}$, and self-humidifying PEMs $\left(\mathrm{Pt}-\mathrm{TiO}_{2} / \mathrm{PEM}\right)$ at $80{ }^{\circ} \mathrm{C}$ and dry conditions presented the open circuit voltage $(\mathrm{OCV})$ values of $0.82 \mathrm{~V}, 0.91 \mathrm{~V}$, and $0.96 \mathrm{~V}$, respectively, which stemmed from lower gas cross-over (leakage) of nanocomposite PEMs.

(a)
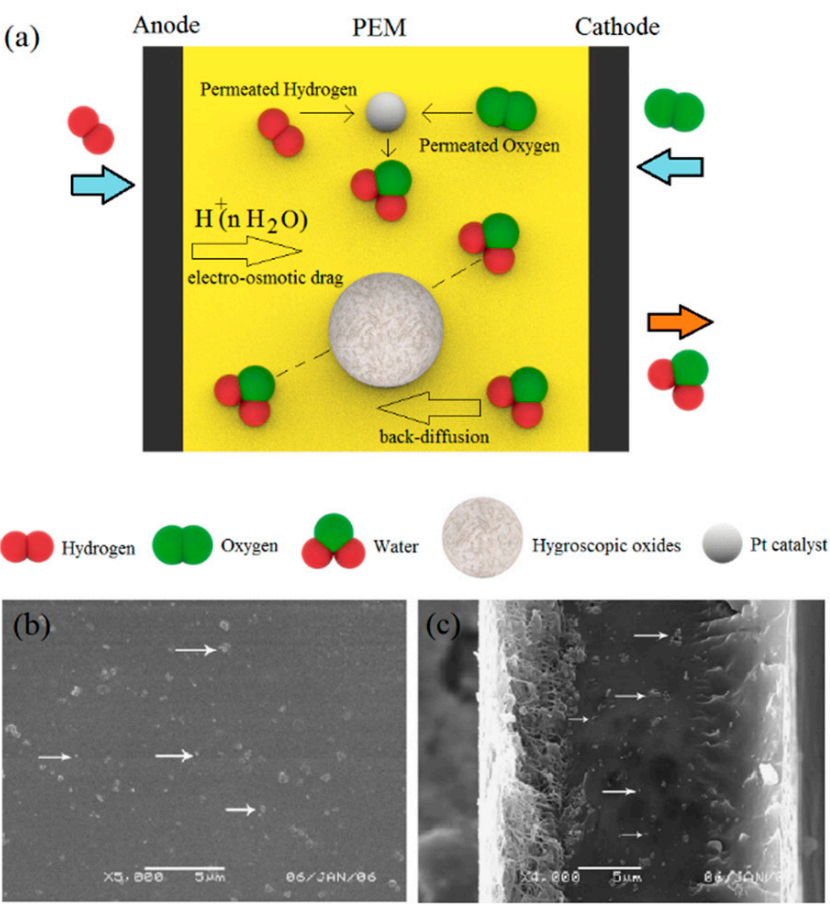

(d)
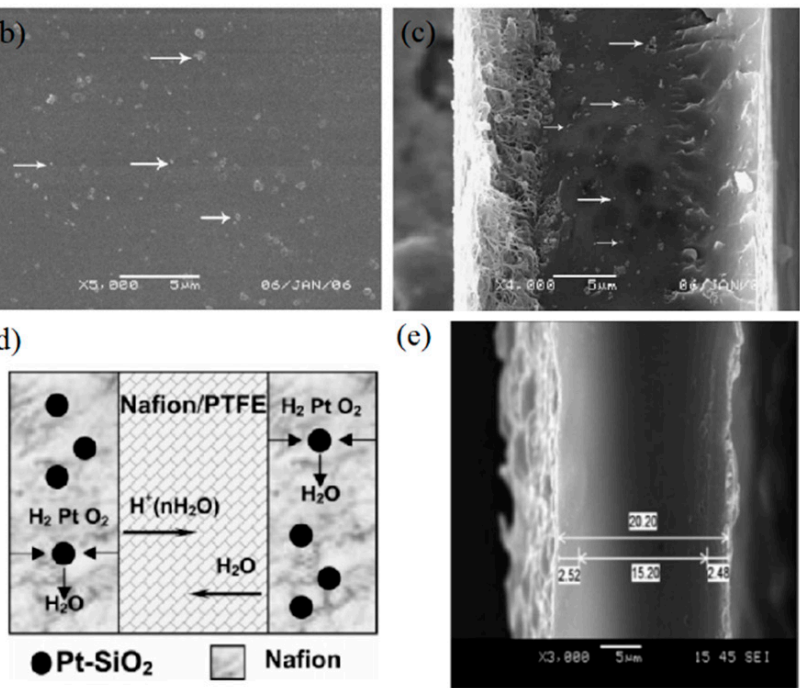

(e)
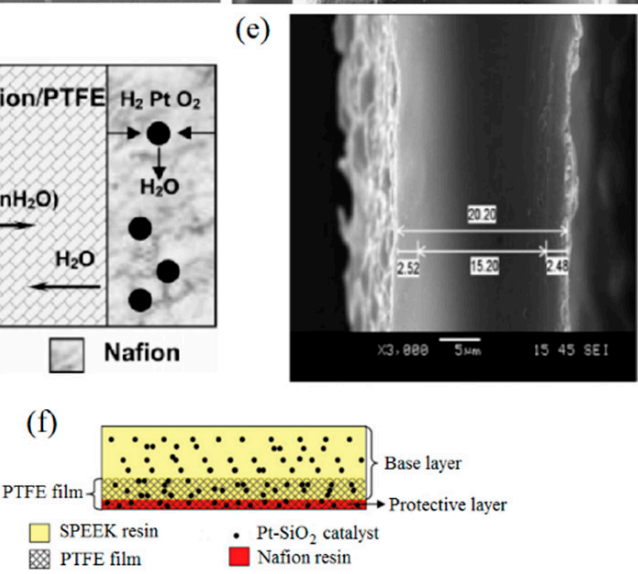

Figure 2. (a) Basic concept of self-humidifying PEMs endowed with hygroscopic oxides and $\mathrm{Pt}$ catalyst; (b) surface and (c) cross-section of $\mathrm{Pt}-\mathrm{SiO}_{2} / \mathrm{Nafion} / \mathrm{PTFE}$ (polytetrafluoroethylene) membranes (reprinted with permission from [50]); (d) schematic and (e) SEM image of ultra-thin PEM with Nafion/PTFE as a central layer and $\mathrm{Pt}-\mathrm{SiO}_{2} / \mathrm{Nafion}$ as side layers (reprinted with permission from [51]); (f) schematic representation of $\mathrm{Pt}-\mathrm{SiO}_{2} / \mathrm{SPEEK} / \mathrm{PTFE} / \mathrm{Nafion} / \mathrm{Pt}-\mathrm{SiO}_{2}$ self-humidifying PEM (reprinted with permission from [52]).

Thus, self-humidifying PEMs incorporated with hygroscopic oxides demonstrated superb performance, where Nafion containing $0.09 \mathrm{mg} \mathrm{cm}^{-2} \mathrm{Pt}$ and $1.0 \mathrm{wt} \% \mathrm{SiO}_{2}$ at $80{ }^{\circ} \mathrm{C}$ and quite 
dry conditions exhibited an identical polarization curve with plain Nafion performing at the same temperature in fully humidified conditions [49]. Despite the excellent electrochemical performance of recast self-humidifying PEMs, the mechanical stability of these thin membranes was still problematic. Therefore, Wang et al. used a porous film of polytetrafluoroethylene (PTFE) as the support and prepared $\mathrm{Pt}-\mathrm{SiO}_{2} / \mathrm{Nafion} / \mathrm{PTFE}$-reinforced composite PEM $(25 \mu \mathrm{m})$ [50]. They reported that reinforced self-humidifying PEMs demonstrated a much lower swelling ratio and improved mechanical strength. The distribution of silica-supported Pt catalysts on the surface and cross-section of self-humidifying PEM is shown by the arrows in Figure 2b,c. The ultra-thin self-humidifying membrane with $25 \mu \mathrm{m}$ in thickness exhibited a maximum power density value of $1.29 \mathrm{~W} \mathrm{~cm}^{-2}$ at $80^{\circ} \mathrm{C}$ in dry conditions, which was greater than that of plain Nafion $(50 \mu \mathrm{m})$ at $80^{\circ} \mathrm{C}$ in humidified conditions $\left(1.21 \mathrm{~W} \mathrm{~cm}^{-2}\right)$. However, reducing the thickness caused a significant increase in the $\mathrm{H}_{2}$ cross-over rate; as for self-humidifying PEM $(25 \mu \mathrm{m})$, this value increased approximately 10 -fold compared to plain Nafion $(50 \mu \mathrm{m})$ at $60{ }^{\circ} \mathrm{C}$ [50]. Although permeated reactants are consumed to humidify the membrane in this method, their reaction on the cathode surface might cause mixed potential and increase cathode polarization. Moreover, permeated reactants might participate in electrochemical/chemical reactions that lead to the formation of $\mathrm{H}_{2} \mathrm{O}_{2}$ or destructive radicals as by-products. To this end, Zhu et al. developed an ultra-thin $(20 \mu \mathrm{m}) \mathrm{PEM}$ comprising $\mathrm{Pt}-\mathrm{SiO}_{2} / \mathrm{Nafion}$ as side layers and a Nafion-impregnated PTFE as the central layer, according to Figure 2d [51]. First of all, Nafion solution was poured onto PTFE film with $0.3-0.5 \mu \mathrm{m}$ pore size and a thickness of $15 \mu \mathrm{m}$. Then, the PEM ink containing $0.17 \mathrm{mg} \mathrm{cm}^{-2}$ catalysts $\left(\mathrm{Pt} / \mathrm{SiO}_{2}\right)$ was sprayed on both its sides, as shown in Figure $2 \mathrm{e}$. The PEM with a sandwich structure suppressed the permeated gases for humidification more effectively, in spite of the lower thickness. Thus, the ultra-thin membrane represented the peak power density and OCV value of $1.4 \mathrm{~W} \mathrm{~cm}^{-2}$ and $1.032 \mathrm{~V}$ at $60^{\circ} \mathrm{C}$ under dry $\mathrm{H}_{2} / \mathrm{O}_{2}$ conditions, respectively. Inhibiting the possibility of electron conduction through self-humidifying membranes (short circuit), due to the existence of a network of Pt metallic particles, was another benefit of their multilayer design.

Similarly, Zhang et al. fabricated a PTFE-reinforced self-humidifying membrane, including a low-cost SPEEK base layer $(21 \mu \mathrm{m})$ and an extremely thin Nafion protective layer $(3 \mu \mathrm{m})$ near the cathode [52]. As illustrated in Figure 2f, the Nafion resin incorporated with $\mathrm{Pt}-\mathrm{SiO}_{2}$ catalysts was intended to protect the $\mathrm{Pt}-\mathrm{SiO}_{2} / \mathrm{SPEEK}$ layer from radical-induced chemical degradation as a result of $\mathrm{H}_{2} \mathrm{O}_{2}$ formation at the cathode. In addition, the Pt-SiO$/ 2$ SPEEK/PTFE/Nafion/Pt-SiO membrane with a total Pt loading of $0.0022 \mathrm{mg} \mathrm{cm}^{-2}$ showed a great $\mathrm{OCV}$ value of $0.98 \mathrm{~V}$, which was presumably due to the significantly lower reactant cross-over of the SPEEK membrane. In addition, this proposed self-humidifying PEM sustained $250 \mathrm{~h}$ operation with dry reactants without significant performance deterioration.

In another study, silica aerogel (SA) was used by Tsai et al. as a support for Pt [54], and the Pt-SA/Nafion self-humidifying membrane demonstrated promising performance both in terms of proton conductivity and water retention, due to SA's high surface area and porosity. Moreover, it was shown that Pt-SA particles were distributed in the Nafion matrix without agglomeration. Still, in another study, it has been shown that silica nanoparticles tend to aggregate and leach out in humidity cycles or upon exposure to hot water [55]. To solve this issue, two remedies were presented by the authors. Firstly, the surface modification of existing materials or use of other inorganic additives with lower water solubility was encouraged. Furthermore, the strength of the organic/inorganic interface was reportedly crucial in terms of stability and stress alleviation in humidity cycles.

Alternatively, zeolites and clays can be used in self-humidifying membranes because of their excellent water retention properties [56,57]. Zeolites are hydrophilic, porous, and largely non-conductive materials that are mainly made of silicon, aluminum, and oxygen elements [56]. In an effort to develop self-humidifying PEM, Son et al. proposed a Pt-zeolite HY/Nafion composite membrane [58]. First, zeolite $\mathrm{HY}$ was treated dropwise with aqueous solution of $\mathrm{PtCl}_{4}$. Then, exchanged $\mathrm{Pt}$ was reduced by means of $\mathrm{NaBH}_{4}$. Finally, the platinized zeolite was added to Nafion solution, and the membranes with a thickness of $50 \mu \mathrm{m}$ were cast subsequent to sonication. As far as self-humidification efficacy is 
concerned, the catalyst loading, their size, and their distribution are of great importance. Figure 3a depicts the TEM image of $\mathrm{Pt} /$ zeolite HY powder in which the Pt size seems to be around $3 \mathrm{~nm}$. Son et al. observed that the composite membrane comprising $0.65 \mathrm{wt} \% \mathrm{Pt}$-zeolite $\left(0.03 \mathrm{mgPt} \mathrm{cm}^{-2}\right)$ showed the optimum electrochemical performance and lowest ohmic resistance (approximately $0.33 \Omega \mathrm{cm}^{2}$ ). However, the prepared membrane with $0.22 \mathrm{wt} \% \mathrm{Pt}$-zeolite $\left(0.01 \mathrm{mgPt} \mathrm{cm}{ }^{-2}\right)$ failed to provide sufficient water production sites for dry operation and exhibited low proton conductivity in dry conditions. On the other hand, the incorporation of $1.5 \mathrm{wt} \% \mathrm{Pt}$-zeolite $\left(0.07 \mathrm{mgPt} \mathrm{cm}^{-2}\right)$ in the Nafion led to a rise in cell resistance (more than $0.62 \Omega \mathrm{cm}^{2}$ ). The I-V (polarization) curves of these three nanocomposite PEMs at $50{ }^{\circ} \mathrm{C}$ and dry condition are illustrated in Figure $3 \mathrm{~b}$, which showcases the stable performance of $0.65 \mathrm{wt} \% \mathrm{Pt} /$ zeolite PEM even at high current densities.

Another additive category that can be substituted for oxide particles is clays. In a study by Zhang et al. [59], a self-humidifying membrane incorporated with Pt-clay was introduced. The Cloisite $20 \mathrm{~A}$ was modified using an organic modifier prior to deposition of Pt onto a planar clay surface by the chemical vapor deposition (CVD) method. Then, Pt particles were immobilized on the exfoliated clay structure with a lateral size of up to $200 \mathrm{~nm}$, followed by calcination and reduction processes. The additive synthesis method and membrane fabrication process are shown schematically in Figure 3c. Eventually, Pt-clay nanoparticles were prepared and mixed with Nafion to obtain Pt-clay/Nafion solution following sonication and mechanical agitation. As presented in Figure $3 \mathrm{~d}$, the obtained self-humidifying PEM with a thickness of $60 \mu \mathrm{m}$ suggested great fuel cell performance and showed $170 \%$ higher power density at $0.5 \mathrm{~V}$ than the plain Nafion 112 membrane with identical thickness, under dry conditions at $60^{\circ} \mathrm{C}$. In addition, the Pt loading in the membrane was substantially low $\left(0.004 \mathrm{mgPt} \mathrm{cm}^{-2}\right)$ compared to some other previous self-humidifying PEMs. Quite similarly, Narayanamoorthy et al. benefited from amino-functionalized clay (AC) as a support for Pt nanoparticles in the self-humidifying PEM [60]. In summary, they added 3-aminopropyltriethoxysilane to a solution of magnesium chloride in ethanol. Then, the obtained slurry was stirred, and the precipitate was collected subsequent to washing with ethanol. In the next step, the solution casting was used to prepare the AC/Nafion PEMs. $\mathrm{Pt}$ nanoparticles, on the other hand, were embedded by the sonication of a mixture of $\mathrm{Pt}$ precursor $\left(\mathrm{H}_{2} \mathrm{PtCl}_{6} \cdot \mathrm{H}_{2} \mathrm{O}\right), \mathrm{Pt}-\mathrm{AC}$ aqueous solution, and Nafion resin. Eventually, Pt-AC/Nafion membranes were prepared by the solution casting method as well. It was argued and proven by SEM images and elemental mapping that AC sheets tend to be placed in the hydrophilic/hydrophobic interface of Nafion and consequently, they create a uniform distribution. In addition, $\mathrm{Pt}$ nanoparticles with an average size of $2-5 \mathrm{~nm}$ exhibited even distribution, according to the HRTEM images [60]. However, fuel cell or proton conductivity data at anhydrous condition were not reported to assess the self-humidifying ability of their newly developed nanocomposite PEM.

In another study [61], layered double hydroxides (LDHs) were employed as 2D nanostructured anionic clay, and Pt particles were anchored on their surface by the CVD method. Eventually, ultra-thin self-humidifying PEMs with a thickness of $9 \mu \mathrm{m}$ were developed to reduce the ohmic resistance and electro-osmotic drag as much as possible. In comparison with plain Nafion and Pt-clay/Nafion membranes with the same thickness $(9 \mu \mathrm{m})$, Pt-LDHs/Nafion exhibited superior fuel cell performance at dry conditions. The results for maximum power density at $60^{\circ} \mathrm{C}$ and $\mathrm{OCV}$ exhibited an improvement of $34 \%$ and $20 \%$ compared to plain Nafion. In addition, there was an increase of $25 \%$ and $6 \%$ in comparison with the Pt-clay/Nafion sample, respectively. Moreover, ultra-thin membrane enhanced the water management capability of PEMs and reduced the risk of anode drying while operating at high current densities. Thus, the addition of Pt-LDHs did not decrease the hydronium ions' mobility. Additionally, the uniform distribution and small size of LDHs have significantly improved the mechanical and gas barrier properties of the ultra-thin Pt-LDHs/Nafion membrane. Reportedly, the high aspect ratio of 2D LDHs has suppressed the hydrogen cross-over rate up to $82 \%$ compared to plain Nafion, as Figure 3e indicates, which manifests itself as well in an obtained higher OCV value for the $\mathrm{Pt}-\mathrm{LDH} / \mathrm{Nafion}$ membrane. 


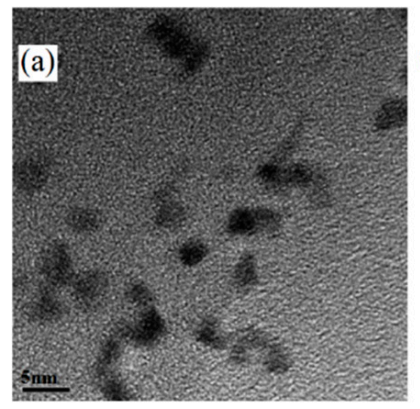

(b)

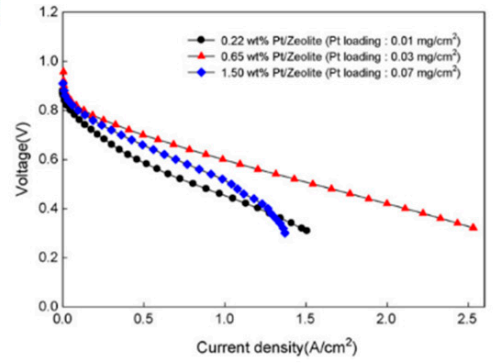

(c)

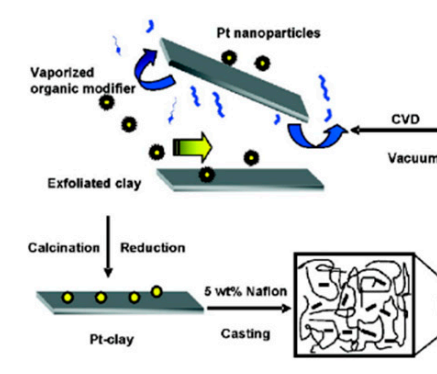

(d)

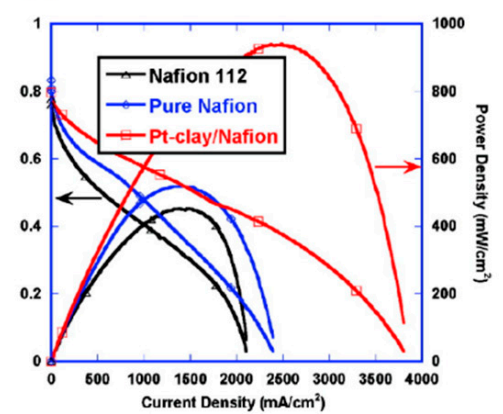

(e)
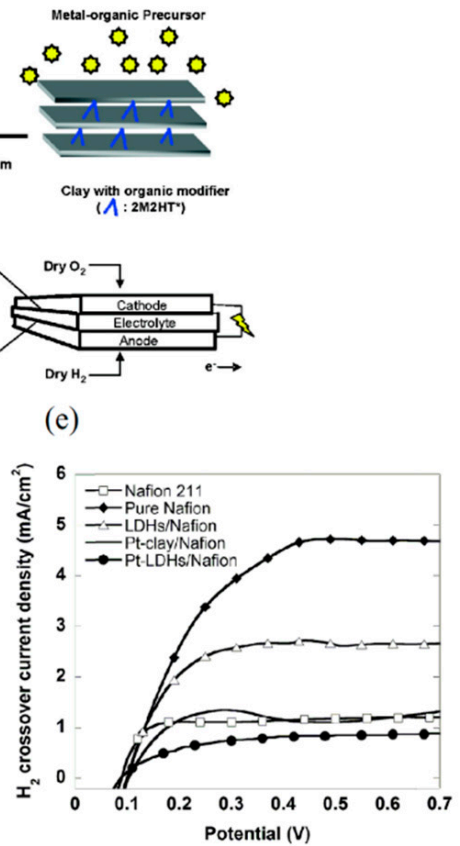

Figure 3. (a) TEM image of Pt/zeolite powder for self-humidification purpose and (b) I-V (polarization) curves of Pt-zeolite PEMs with different catalyst loadings at $50{ }^{\circ} \mathrm{C}$ in dry conditions (reprinted with permission from [58]); (c) process of exfoliated Pt-clay/Nafion membrane preparation and (d) polarization curves for plain Nafion and Pt-clay Nafion membrane under dry conditions at $60{ }^{\circ} \mathrm{C}$ (reprinted with permission from [59]); (e) hydrogen cross-over of plain Nafion, $\mathrm{Pt}$-clay/Nafion, and Pt-LDHs/Nafion membrane (reprinted with permission from [61]). LDH: layered double hydroxides.

\section{Self-Humidifying PEMs Incorporated with Highly Proton-Conductive Additives}

Another category of fillers used in the self-humidifying PEMs was materials with good proton conduction characteristics, while maintaining a sufficient amount of hydration within the membrane for operation at anhydrous fuel cell conditions. These materials can be exemplified by zirconium phosphate, sulfated zirconia, sulfonated materials, and phosphotungstic acid. Figure 4a depicts an overview of the role of these additives in the PEM.

To this end, Lee et al. first prepared the Pt-Nafion by means of the equilibrium impregnation reduction method, in which membranes were equilibrated with a $\mathrm{Pt}\left(\mathrm{NH}_{3}\right)_{4} \mathrm{Cl}_{2}$ solution, followed by reduction by $\mathrm{NaBH}_{4}$ solution at $\mathrm{pH}=13$ for 5 to $60 \mathrm{~min}$ in order to achieve the lowest ohmic resistance [62]. Subsequently, they took tentative steps and added zirconium phosphate $(\mathrm{ZrP})$ with an average size of about $11 \mathrm{~nm}$ into Pt-Nafion via in-situ exposure to $\mathrm{ZrOCl}_{2}$ solution [62]. $\mathrm{ZrP}$ is a proton conductive $\left(10 \mathrm{mS} \mathrm{cm}^{-1}\right.$ at room temperature [62]), hydrophilic material that has shown promising features for the mechanical and thermal stability improvement of composite membranes as well [63]. The Pt-ZrP/Nafion self-humidifying membrane exhibited greater cell performance in comparison with $\mathrm{Pt}-\mathrm{Nafion}$ at $80{ }^{\circ} \mathrm{C}$ in dry conditions, albeit slightly lower proton conductivity, which is due to the 
intrinsically lower proton conductivity of $\mathrm{ZrP}$ [62]. In other words, the room-temperature proton conductivity of Pt-Nafion $\left(72 \mathrm{mS} \mathrm{cm}^{-1}\right.$ ) dropped to 63 and $54 \mathrm{mS} \mathrm{cm}^{-1}$ upon exposure to $0.5 \mathrm{M}$ and $2 \mathrm{M} \mathrm{ZrOCl}_{2}$ solution, respectively.

Moreover, sulfated zirconia (SZ) is a recognized inorganic super-acid with proton conductivity above $40 \mathrm{mS} \mathrm{cm}^{-1}$ at $70{ }^{\circ} \mathrm{C}$ [64]. Acidic moieties on the surface of zirconia have enabled Nafion/SZ membranes to exhibit higher proton conductivity and fuel cell performance, particularly at low relative humidity (RH) (20\%), as Navarra et al. reported [65]. In fact, the addition of SZ will boost the proton conductivity of membranes in two ways. First, a slight rise in the WU of PEMs due to the hygroscopic nature of SZ can improve the vehicular mechanism for proton conduction [7]. On the other hand, in the hydrated state, Lewis acid sites are turned into Bronsted acid sites and contribute to proton conduction derived from the "Grotthuss mechanism" [7,66], as shown in Figure 4b. In a study by Mossayebi et al., SPEEK incorporated with well-distributed SZ nanoparticles (about $20 \mathrm{~nm}$ in diameter) exhibited considerably enhanced mechanical properties and proton conductivity compared to a plain SPEEK membrane [67]. In this regard, Zhang et al. developed a self-humidifying PEM based on a SPEEK membrane incorporated with Pt-SZ nanoparticles [68]. They treated zirconia in sulfuric acid solution $(0.5 \mathrm{M}, 60 \mathrm{~min})$, followed by the drying and calcination of solid particles at $600{ }^{\circ} \mathrm{C}$ for $3 \mathrm{~h}$. Then, $\mathrm{Pt}$ particles were deposited on a SZ support in the $\mathrm{H}_{2} \mathrm{PtCl}_{6}$ solution and eventually, they were reduced by hydrogen at $200^{\circ} \mathrm{C}$. The obtained Pt-SZ catalysts with an average size of $10 \mathrm{~nm}$ are shown in Figure 4c. Finally, Pt-SZ catalysts were added to SPEEK solution with a degree of sulfonation (DS) of $67 \%$ and stirred to obtain homogenous solution. Pt-SZ/SPEEK membranes with a thickness of $24 \mu \mathrm{m}$ were prepared after the casting process. As expected, Pt-SZ/SPEEK membranes exhibited higher WU and proton conductivity in comparison with plain SPEEK and hence superior fuel cell performance in dry conditions, as can be seen in Figure $4 \mathrm{~d}$. While additive-free SPEEK exhibited OCV value of $0.96 \mathrm{~V}$ in dry conditions, Pt-SZ/SPEEK PEM demonstrated an incredibly higher OCV of $1.015 \mathrm{~V}$, which manifests its high efficiency in reactant cross-over suppression. However, this improvement in OCV was less significant in humidified conditions, where Pt-SZ/SPEEK and SPEEK membranes showed OCV values of 1.018 and $1.008 \mathrm{~V}$, respectively. In addition, Zhang et al. proved the water production at dry operation using IR spectrum [69]. To this end, self-humidifying PEM along with additive-free SPEEK were dried and exposed to dry $\mathrm{H}_{2}$ and $\mathrm{O}_{2}$ for two days at $60{ }^{\circ} \mathrm{C}$. Unlike plain SPEEK, the nanocomposite membrane showed a noticeable peak at $3450 \mathrm{~cm}^{-1}$, which is attributed to $\mathrm{OH}$ stretching. They also investigated the durability of a Pt-SZ/SPEEK membrane under OCV and normal operation fuel cell tests. As indicated in Figure 4e, the performance of this self-humidifying PEM did not drop during $50 \mathrm{~h}$ of fuel cell tests, and the permeated reactants were only consumed to produce water. In fact, even though the self-humidifying PEMs demonstrated quite an equivalent $\mathrm{H}_{2}$ cross-over value to plain PEM (approximately $1 \mathrm{~mA} \mathrm{~cm}^{-2}$ ), the permeated reactants do not participate in radical-induced chemical degradation, nor in creating mixed potential at the cathode side. Moreover, the ohmic resistance of plain SPEEK and SPEEK nanocomposite membranes incorporated with $\mathrm{Pt}-\mathrm{SiO}_{2}$ and Pt-SZ was examined as a function of current density [69]. While a Pt-SiO${ }_{2} / \mathrm{SPEEK}$ membrane with an ion exchange capacity (IEC) of $1.73 \mathrm{mmol} \mathrm{g}^{-1}$ could reduce the ohmic resistance in dry condition to some extent, Pt-SZ/SPEEK with an IEC value of $1.94 \mathrm{mmol} \mathrm{g}^{-1}$ exhibited quite comparable resistance (at dry condition) with a fully humidified plain SPEEK membrane, as Figure $4 \mathrm{f}$ depicts. Besides, SPEEK membranes incorporated with $\mathrm{Pt}-\mathrm{SiO}_{2}$ and $\mathrm{Pt}-\mathrm{SZ}$ illustrated a significant improvement in proton conductivity at $\mathrm{RH}=10 \%$ and $60{ }^{\circ} \mathrm{C}$, which was more pronounced in the case of Pt-SZ. The reason might be the fact that $\mathrm{SiO}_{2}$ is a non-conductive material, but $\mathrm{SZ}$ is a conductive material with unique water retention properties.

Another interesting observation could be the almost constant ohmic resistance of SPEEK-based PEMs in a wide range of current densities [69]. In contrast with Nafion-based membranes, water back-diffusion in high current densities did not affect the ohmic resistance of thin SPEEK-based membranes. Unlike SPEEK membranes, the proton conduction of PFSA membranes mostly relies on vehicular mechanism rather than the Grotthuss mechanism, considering their well-defined phase 
separation stemmed from the Teflon-like backbone (Figure 1b, chemical structure of Nafion) [7]. Thereby, it seems that the generated water at high current densities can contribute to the formation of proton conduction channels in Nafion more efficiently. Bi et al. added both $\mathrm{SiO}_{2}$ and $\mathrm{SZ}$ nanoparticles into the Nafion matrix, without Pt incorporation, and developed the hybrid $\mathrm{SiO}_{2}-\mathrm{SZ} / \mathrm{Nafion}$ membrane with $50 \mu \mathrm{m}$ in thickness [70]. The addition of both agents resulted in water uptake and proton conductivity (dry, $60{ }^{\circ} \mathrm{C}$ ) values of $54.8 \%$ and $65 \mathrm{mS} \mathrm{cm}^{-1}$, while the figures for recast Nafion were $30.2 \%$ and $26 \mathrm{mS} \mathrm{cm}^{-1}$. The simultaneous presence of both additives has presumably improved both proton conduction mechanisms and led to an excellent single cell performance in dry conditions, in which a maximum power density value of $0.98 \mathrm{~W} \mathrm{~cm}^{-2}$ was obtained (about $50 \%$ improvement compared to recast Nafion).

(a)

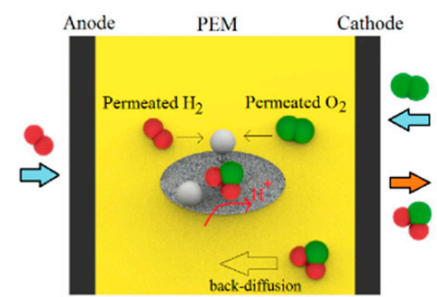

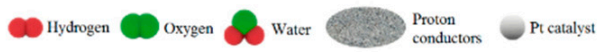
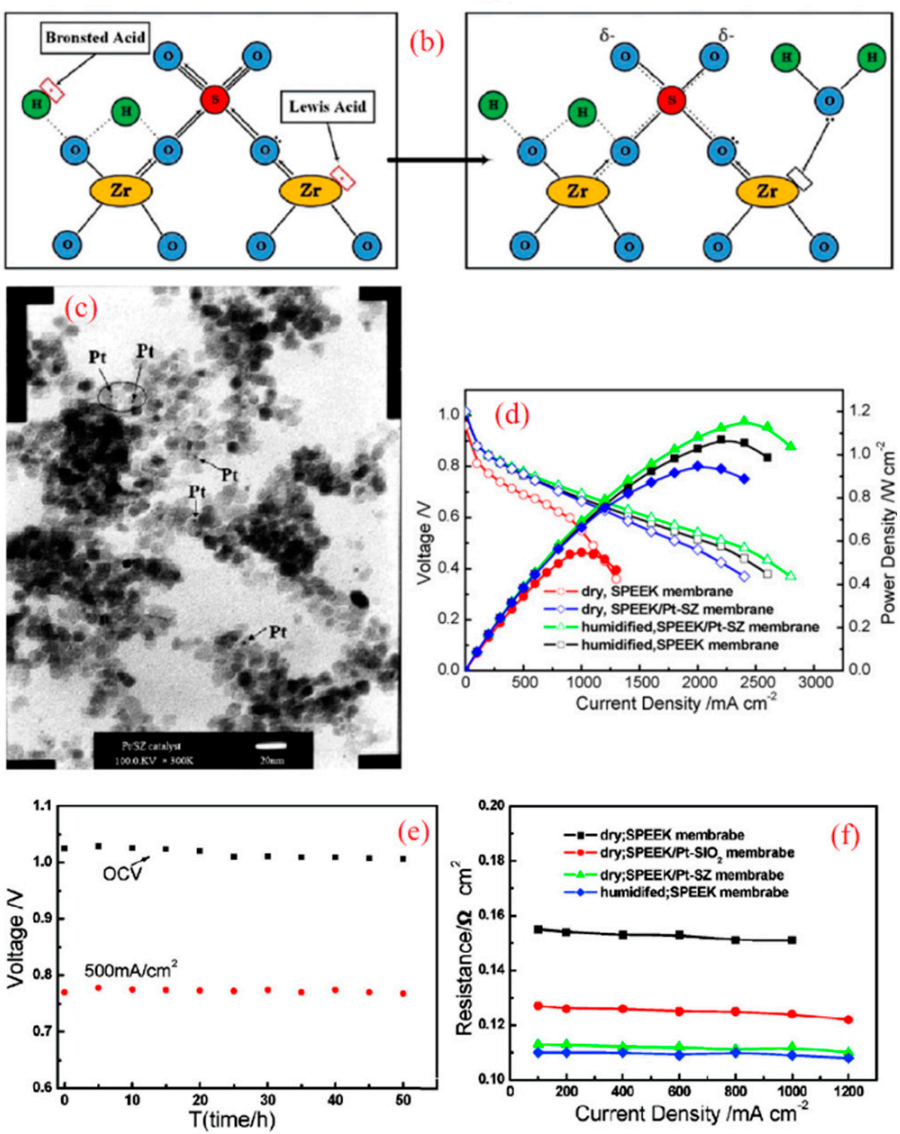

Figure 4. (a) Schematic demonstration of a self-humidifying PEM incorporated with proton conductors, (b) Bronsted acid sites act as additional acidic sites for proton conduction in sulfated zirconia (SZ) (reprinted with permission from [67]); (c) TEM image of Pt-SZ nanoparticles with Pt loading of 2 wt \% and (d) fuel cell performance of plain SPEEK and Pt-SZ/SPEEK membranes at $60{ }^{\circ} \mathrm{C}$ (reprinted with permission from [68]); (e) $50 \mathrm{~h}$ fuel cell test for Pt-SZ/SPEEK at $60^{\circ} \mathrm{C}$ and dry condition and (f) areal resistance of plain and nanocomposite SPEEK membranes as a function of current density (reprinted with permission from [69]). 
Likewise, the modification of hygroscopic materials with acidic sources has shown great potential for the simultaneous improvement of water retention and proton conductivity in the PEMs [71]. Yang et al. functionalized $\mathrm{SiO}_{2}$ particles by dispersing them in a $3 \mathrm{M}$ sulfuric acid solution at $150-160{ }^{\circ} \mathrm{C}$ and fabricated sulfonated $\mathrm{Pt}-\mathrm{SiO}_{2} / \mathrm{Nafion}$ self-humidifying PEMs with an additive content of $1.5-3.0 \mathrm{wt} \%$ [72]. The sulfonated $\mathrm{Pt}-\mathrm{SiO}_{2} / \mathrm{Nafion}$ nanocomposite $\mathrm{PEM}$ with $1.5 \mathrm{wt} \%$ additive content demonstrated comparable PEFC performance at dry condition and $80{ }^{\circ} \mathrm{C}$ with the fully humidified Nafion with the same thickness, where the $0.45 \mathrm{~A} \mathrm{~cm}^{-2}$ was achieved at $0.6 \mathrm{~V}$. In another study, various media such as $\mathrm{H}_{2} \mathrm{SO}_{4}$ and $\mathrm{HSO}_{3} \mathrm{Cl}$ for the sulfonation process of $\mathrm{Pt}-\mathrm{SiO}_{2}$ particles were used, and it was found that sulfonation with $\mathrm{Na}_{2} \mathrm{SO}_{4}$ leads to incredibly high proton conductivity $\left(60 \mathrm{mS} \mathrm{cm}^{-1}, 60^{\circ} \mathrm{C}\right)$ and $\mathrm{OCV}$ value $(0.93 \mathrm{~V})$ at dry conditions for $\mathrm{Pt}-\mathrm{SiO}_{2} / \mathrm{Nafion}$ self-humidifying PEM because of the smallest $\mathrm{Pt}$ nanoparticle size $(1.92 \mathrm{~nm})$ and excellent quality of additive dispersion [73].

Another category of proton-conductive additives is heteropolyacids (HPAs), through which both the proton conductivity and water retention of PEMs can be improved. Their well-known Keggin structure is presented in Figure 5a. Nonetheless, HPAs such as phosphotungstic acid (PTA) with the chemical formula of $\mathrm{H}_{3} \mathrm{PW}_{12} \mathrm{O}_{40}$ leach out of membranes due to their high solubility in water [74]. Thereby, they are either supported by high surface oxides, e.g., $\mathrm{SiO}_{2}$ and $\mathrm{TiO}_{2}$ [75] or replaced by heteropolysalts; i.e., the $\mathrm{H}^{+}$is substituted with larger cations, namely $\mathrm{Cs}^{+}$or $\mathrm{Rb}^{+}$[76]. To this end, Zhang et al. synthesized $\mathrm{Pt}-\mathrm{Cs}_{2.5} \mathrm{H}_{0.5} \mathrm{PW}_{12} \mathrm{O}_{40}$ catalyst by the titration method to be employed in the development of a new SPEEK-based self-humidifying PEM (Pt-Cs $s_{2.5} /$ SPEEK) [77]. The Pt-Cs $2.5 /$ SPEEK membranes, with $24 \mu \mathrm{m}$ in thickness and $15 \mathrm{wt} \%$ catalyst loading, were obtained by the solution casting method. As illustrated in Figure $5 \mathrm{~b}, \mathrm{Pt}-\mathrm{Cs}_{2.5} / \mathrm{SPEEK}$ membranes exhibited high stability and demonstrated negligible weight reduction after immersion in water and sulfuric acid solution for $100 \mathrm{~h}$. On the other hand, almost the entire additive was extracted in water for PTA/SPEEK membranes, which indicates the reliability of $\mathrm{Pt}-\mathrm{Cs}_{2.5}$ catalysts for use in the aqueous environment of PEMs. In addition, $\mathrm{Pt}-\mathrm{Cs}_{2.5} / \mathrm{SPEEK}$ showed a higher IEC value than plain SPEEK membranes, suggesting that new acidic sites for proton conduction are provided. Furthermore, the WU of self-humidifying PEM was enhanced by about $50 \%$ as a result of the strong interaction between heteropolysalt and water molecules. Consequently, the high proton conductivity of $53 \mathrm{mS} \mathrm{cm}^{-1}$ was reported for Pt-Cs $2.5 / \mathrm{SPEEK}$ PEM at $60{ }^{\circ} \mathrm{C}$, while the result for the plain SPEEK membrane was $42 \mathrm{mS} \mathrm{cm}^{-1}$ [77]. As can be seen in Figure $5 c$, Pt-Cs $s_{2.5} /$ SPEEK PEM exhibited almost similar fuel cell performance to humidified plain SPEEK membranes at $60^{\circ} \mathrm{C}$. It is worth mentioning that nanocomposite SPEEK membranes showed higher OCV value in dry conditions $(0.99 \mathrm{~V})$ in comparison with additive-free PEM $(0.96 \mathrm{~V})$. However, in wet conditions, both membranes demonstrated the identical value of $1.01 \mathrm{~V}$.

Basically, PEMs require a minimum level of hydration and hydrophilic domains connectivity for the proton conduction process; this limit is known as the "percolation threshold" [32,78]. Interestingly enough, it has been revealed that the addition of HPAs can significantly reduce the percolation threshold for membranes and thus, it creates organized water channels at lower water content [79]. Peighambardoust et al. developed Pt-Cs $2.5 /$ SPEEK PEMs (with a thickness of $45 \mu \mathrm{m}$ ) based on SPEEK with sulfonation degrees between $50 \%$ and $70 \%$ and $\mathrm{Pt}^{-\mathrm{Cs}_{2.5}}$ catalyst loading ranging from 10 to $20 \mathrm{wt} \%$ [80]. SPEEK membranes with a DS of about $65 \%$ were chosen as the optimal PEM, according to its acceptable mechanical properties and good proton conductivity. The obtained results showed that the $\mathrm{Pt}-\mathrm{Cs}_{2.5}$ catalyst loading of $10 \mathrm{wt} \%$ could not provide sufficient water production and acidic sites within the membrane, nor could the $20 \mathrm{wt} \% \mathrm{Pt}-\mathrm{Cs}_{2.5}$ catalyst exhibit the expected performance due to catalyst agglomeration and phase segregation. Hence, $\mathrm{Pt}-\mathrm{Cs}_{2.5}$ catalyst loading of $15 \mathrm{wt} \%$ with $1.25 \mathrm{wt} \% \mathrm{Pt}$ led to the highest proton conductivity. The optimum self-humidifying PEM displayed better performance at dry conditions and $60{ }^{\circ} \mathrm{C}$ than Nafion 117 in humidified conditions at the same temperature. In a further step, the thermal, mechanical, and chemical stability of $\mathrm{Pt}-\mathrm{Cs}_{2.5} / \mathrm{SPEEK}$ self-humidifying membranes were investigated [81]. Generally, the addition of $\mathrm{Pt}-\mathrm{Cs}_{2.5}$ catalysts caused a more restricted segmental motion of polymer chains and thus, they increased the glass transition temperature value of SPEEK membranes. Besides, self-humidifying PEMs exhibited 
higher thermal stability below $300^{\circ} \mathrm{C}$ in thermogravimetric analysis (TGA). Figure $5 \mathrm{~d}$ depicts the higher mechanical toughness and strength of $\mathrm{Pt}-\mathrm{Cs}_{2.5} /$ SPEEK PEMs in comparison with additive-free SPEEK, which can be explained by the uniform distribution of nanoparticles in the SPEEK matrix. Moreover, SPEEK membranes incorporated with $15 \mathrm{wt} \% \mathrm{Pt}_{-} \mathrm{Cs}_{2.5}$ demonstrated significantly higher oxidative resistance than plain membranes in a harsh Fenton's test, in which membranes were deliberately exposed to hydrogen peroxide $\left(\mathrm{H}_{2} \mathrm{O}_{2}\right)$ and $\mathrm{Fe}^{2+}$ ions [81]. Hydrogen peroxide has proven to be the key component of destructive radical formation in the PEMs [82]. According to Wang et al. [83], the $\mathrm{Pt}-\mathrm{Cs}_{2.5}$ can efficiently scavenge $\mathrm{H}_{2} \mathrm{O}_{2}$ and instead create water as a by-product of this reaction, as presented in Equation (5).

$$
\mathrm{Cs}_{2.5} \mathrm{H}_{0.5} \mathrm{PW}_{12} \mathrm{O}_{40}+\mathrm{H}_{2} \mathrm{O}_{2} \rightarrow \mathrm{Cs}_{2.5} \mathrm{H}_{0.5} \mathrm{PW}_{12} \mathrm{O}_{40}(\mathrm{O})+\mathrm{H}_{2} \mathrm{O}
$$
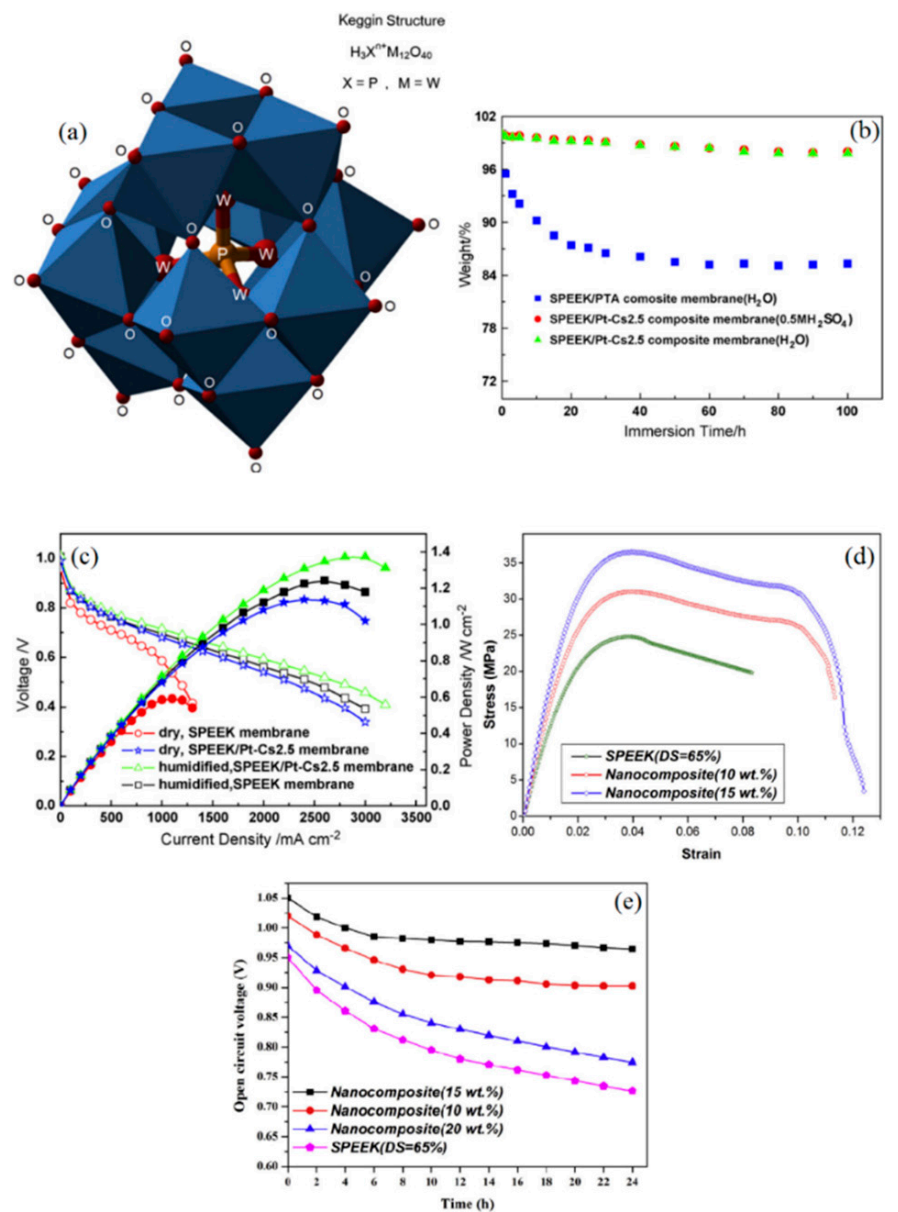

Figure 5. (a) Keggin structure of phosphotungstic acid (PTA) as a proton-conductor additive (reprinted with permission from [80]); (b) durability evaluation of PTA/SPEEK and Pt-Cs s.5. $_{2} /$ SPEK in aqueous and acidic environment and (c) PEFC performance of plain and nanocomposite SPEEK membranes at $60{ }^{\circ} \mathrm{C}$ (reprinted with permission from [77]); (d) stress-strain curves for additive-free and $\mathrm{Pt}-\mathrm{Cs}_{2.5}$ /SPEEK PEMs and (e) open circuit voltage (OCV) test for the stability measurement of plain SPEEK and $\mathrm{Pt}-\mathrm{Cs}_{2.5} / \mathrm{SPEEK}$ PEMs (reprinted with permission from [81]).

As shown in Figure 5e, the excessive incorporation of $\mathrm{Pt}-\mathrm{Cs}_{2.5}$ has resulted in catalyst agglomeration and PEM's inefficiency in providing reaction sites for permeated hydrogen and oxygen, whereas $15 \mathrm{wt} \%$ $\mathrm{Pt}-\mathrm{Cs}_{2.5}$ loading of catalyst yielded high and stable OCV values over a $24 \mathrm{~h}$ test [81]. Moreover, Sayadi et al. measured the $\mathrm{H}_{2}$ cross-over of Pt-Cs $2.5 /$ SPEEK membrane with $15 \mathrm{wt} \%$ catalyst loading and $45 \mu \mathrm{m}$ in thickness by an in situ electrochemical technique at different temperatures $\left(40-80^{\circ} \mathrm{C}\right), \mathrm{RH}$ values 
(40-100\%), and hydrogen partial pressures (40-160 kPa) [84]. It was shown that nanocomposite SPEEK membranes have a substantially lower $\mathrm{H}_{2}$ cross-over rate (below $1 \mathrm{~mA} \mathrm{~cm}{ }^{-2}$ ) than Nafion 117, even though Nafion 117 was almost four times as thick as the nanocomposite PEM. The superior gas barrier properties of $\mathrm{Pt}-\mathrm{Cs}_{2.5} / \mathrm{SPEEK}$ promises lower destructive radical formation and potential chemical degradation [84].

\section{Self-Humidifying PEMs Incorporated with Carbon-Based Additives}

Carbon-based materials have long been utilized as a support for catalysts in fuel cell applications owing to their high surface area and unique properties [85]. The frequently used carbon-based supports are carbon black, carbon nanotubes, carbon nanofiber, and graphene, while graphene oxide is considered a great filler for nanocomposite PEMs as well. In this regard, Figure 6a indicates a self-humidifying PEM endowed with Pt supported upon carbon-based materials.

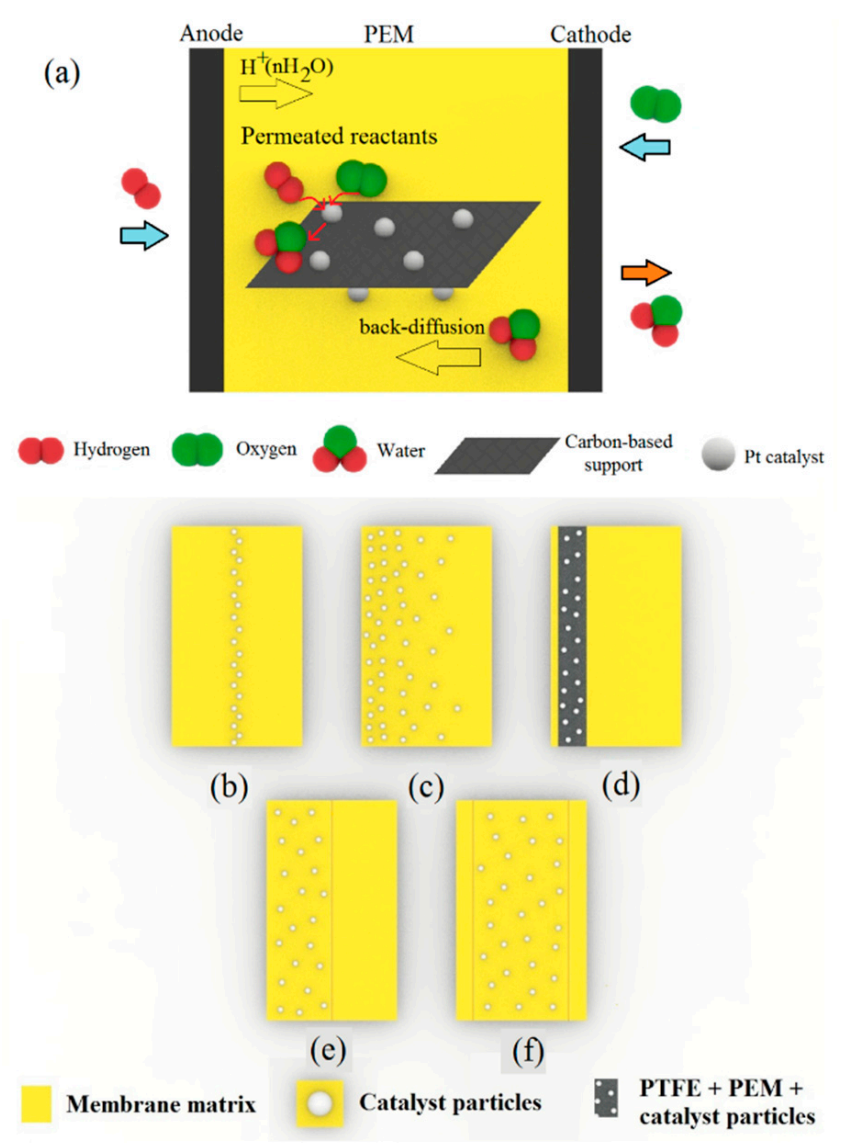

Figure 6. Schematic presentation of (a) a self-humidifying PEM endowed with Pt nanoparticles anchored upon carbon-based supports for better dispersion, (b) Pt-sputtered layer between two plain PEM layers, (c) gradationally dispersed Pt nanoparticles within the PEM, (d) a PTFE-supported $\mathrm{Pt}-\mathrm{C} /$ Nafion layer near the anode, (e) a two-layer composite PEM with a self-humidifying layer near the anode, and (f) a three-layer nanocomposite membrane with a central self-humidifying layer.

However, the incorporation of Pt or Pt-C nanoparticles into the PEMs is likely to cause an electron short circuit due to the high electron conductivity of these additives. To overcome this problem, different multilayer membrane designs were proposed. Kwak et al. sandwiched a sputtered Pt layer between Nafion resins and developed a new Pt/PEM, as depicted in Figure 6b [86]. Although they obtained the optimum value of $0.15 \mathrm{mg} \mathrm{cm}^{-2}$ for Pt loading in the PEM to minimize ohmic resistance and maximize fuel cell performance, this design limited the self-humidification and back-diffusion processes due to its thickness $(150 \mu \mathrm{m})$ and resulted in relatively poor performance because of high 
ohmic resistance [86]. Thus, Wang et al. introduced the equilibrium impregnation-reduction method, by which Pt nanocrystals were gradationally dispersed within the membrane, according to Figure 6c [87]. Their new design could cut off the electron conduction path to some extent and yielded a peak of $1.2 \mathrm{~W} \mathrm{~cm}^{-2}$ in power density at dry conditions and $70^{\circ} \mathrm{C}$. The polarization curves for plain and $\mathrm{Pt} / \mathrm{PEM}$ samples at dry and humidified conditions and $70^{\circ} \mathrm{C}$ are indicated in Figure $7 \mathrm{a}$. Additionally, Figure $7 \mathrm{~b}$ shows the stable operation of self-humidifying PEM at $70{ }^{\circ} \mathrm{C}$ and constant current density of $1.5 \mathrm{~A} \mathrm{~cm}^{-2}$ in which cell voltage reaches a plateau of $0.66 \mathrm{~V}$ after a couple of hours. Nevertheless, the stability of $\mathrm{Pt}$ particles in the long-term operation without the formation of agglomerates is questionable. With an aim to evaluate the durability of Pt/Nafion PEM with a thickness of $50 \mu \mathrm{m}$, Liu et al. performed a prolonged fuel cell test at a fixed current density of $0.5 \mathrm{~A} \mathrm{~cm}^{-2}, 50{ }^{\circ} \mathrm{C}$, and dry $\mathrm{H}_{2} /$ air for $1000 \mathrm{~h} \mathrm{[88] \text {. }}$ Despite the excellent stability and OCV value over the first tens of hours $(0.98-0.99 \mathrm{~V})$, the Pt/Nafion membrane's OCV value dropped to a low of $0.86 \mathrm{~V}$ after $1000 \mathrm{~h}$, whereas the plain Nafion showed quite stable OCV values (0.93-0.97 V) throughout the experiment. Further investigation revealed a surge in hydrogen cross-over value (approximately 100 times greater) after the test. Thus, comparing with plain Nafion, it was concluded that the introduction of pure Pt particles and the resulted phase segregation and $\mathrm{Pt}$ agglomeration after prolonged experiments has accelerated $\mathrm{Pt} / \mathrm{Nafion}$ membrane degradation. One plausible explanation for this observation might be the gradual formation of destructive oxygen radicals due to the permeation of reactants and their reaction on the catalyst surface.

In addition, Liu et al. poured a Nafion solution $(20 \mathrm{wt} \% \mathrm{Pt}-\mathrm{C})$ onto PTFE film and let the $\mathrm{Pt}-\mathrm{C}$ particles settle on the PTFE surface and form a self-humidifying layer at the bottom of the film (Figure 6d), which was associated with the anode side [89]. As Figure 7c indicates, the Pt-C/Nafion membrane showed superior performance at high current densities, despite operation at dry condition and $80^{\circ} \mathrm{C}$. Thus, not only did the thin membrane $(35 \mu \mathrm{m})$ prevent electron conduction through PEM, but also the membrane dehydration in the vicinity of the anode was inhibited. A similar design with the same purpose was proposed by Yang et al. [90], where two layers of $\mathrm{Pt}-\mathrm{C} / \mathrm{Nafion}$ (anode side) and plain Nafion (cathode side) were hot-pressed, as indicated in Figure 6e. It was reported that while operating in dry conditions, $60{ }^{\circ} \mathrm{C}$, and low current densities $\left(<0.5 \mathrm{~A} \mathrm{~cm}^{-2}\right)$, the cell with self-humidifying PEM demonstrated high ohmic resistance. However, at higher current densities up to $1.5 \mathrm{~A} \mathrm{~cm}^{-2}$, the cell resistance plummeted to a low of $32 \mathrm{~m} \Omega$, illustrating the promising performance of self-humidifying PEM at high current densities without anode dehydration. Although this two-layer design could successfully exclude the possibility of electron conduction via PEM, the self-humidifying layer is likely to integrate with the anode catalyst layer during operation and diminish the internal humidification performance. To tackle this concern, Liu et al. devised a three-layer nanocomposite PEM with Pt-carbon nanotubes (CNTs)/Nafion as the central layer $(20 \mu \mathrm{m})$ and two plain Nafion layers $(2.5 \mu \mathrm{m})$ on each side, as can be seen in Figure 6f [91]. The CNTs with a length of several micrometers could act as a bridge between polymer chains and thereby improve the mechanical properties and dimensional stability of $\mathrm{Pt}-\mathrm{CNTs} / \mathrm{Nafion}$. In addition, $\mathrm{Pt}-\mathrm{CNTs} / \mathrm{Nafion}$ membranes demonstrated good PEFC performance with dry reactants at $80^{\circ} \mathrm{C}$, as Figure $7 \mathrm{~d}$ suggests. At the same conditions, a Pt-CNTs/Nafion membrane (N-Pt/CNTs-N membrane) exhibited the OCV value of above $1 \mathrm{~V}$, whereas its counterpart incorporated only with CNT resulted in an OCV value of $0.954 \mathrm{~V}$, which clearly proves the self-humidifying function of the N-Pt/CNTs-N membrane and its indisputable role in permeated fuel suppression [91]. In spite of the high hydrogen cross-over value at $80^{\circ} \mathrm{C}\left(4 \mathrm{~mA} \mathrm{~cm}^{-2}\right)$ for this self-humidifying PEM, the high OCV value is an evident sign of acceptable efficacy for self-humidification purposes.

Functionalized carbon-based supports are another way to exclude the possibility of electron conduction inside the membrane. For instance, Hung et al. used sulfonated carbon nanofiber (CNF)-supported Pt nanoparticles [92]. They dispersed CNFs that were 30-100 nm in diameter and 1-10 $\mu \mathrm{m}$ in length into the Pt precursor solution and then put the mixed solution into a microwave oven. In addition, $\mathrm{Pt}-\mathrm{CNF}$ s were sulfonated using concentrated sulfuric acid at $160{ }^{\circ} \mathrm{C}$, and the sulfonation reaction was confirmed by the formation of new absorption peaks of the Fourier transform 
infrared spectroscopy (FT-IR) spectra. Consequently, the membranes with a thickness of $25 \mu \mathrm{m}$ and $\mathrm{Pt}$ loading of $0.02 \mathrm{mg} \mathrm{cm}^{-2}$ were prepared by means of the solution-casting method [92]. Due to the creation of grafted sulfonic acid groups in the sulfonated $\mathrm{Pt}-\mathrm{CNFs}$, extra proton conductive sites were obtained, as the IEC value for nanocomposite PEM increased from 0.9 to $1.12 \mathrm{meq} \mathrm{g}^{-1}$ subsequent to the sulfonation process. Even more importantly, these additives showed better compatibility with Nafion and distributed quite uniformly, as Pt mapping suggested. In accordance with elemental mapping, the electronic resistance of sulfonated Pt-CNF/Nafion was 40-fold higher than that of non-sulfonated $\mathrm{Pt}-\mathrm{CNF} / \mathrm{Nafion}$, implying that this method can succeed in excluding the electron transport within the PEM. Having considered the aforementioned reasons, it is not surprising that the sulfonated Pt-CNF/Nafion self-humidifying PEM demonstrated superior performance compared to non-sulfonated $\mathrm{Pt}-\mathrm{CNF} / \mathrm{Nafion}$ at dry condition (34\% improvement in power density) [92].

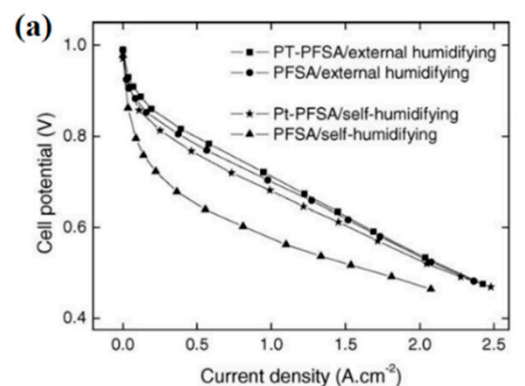

(c)

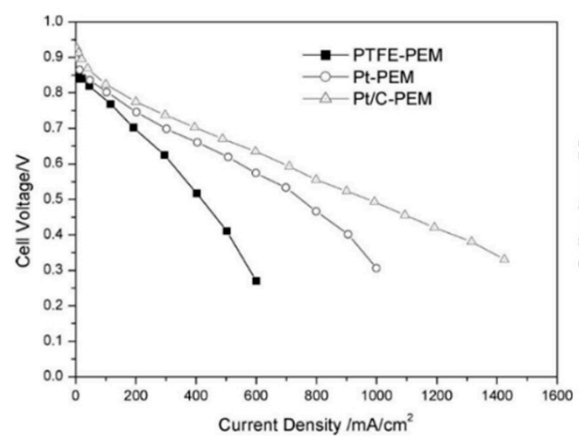

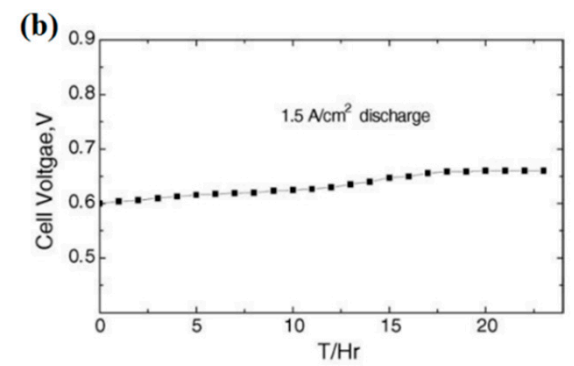

(d)

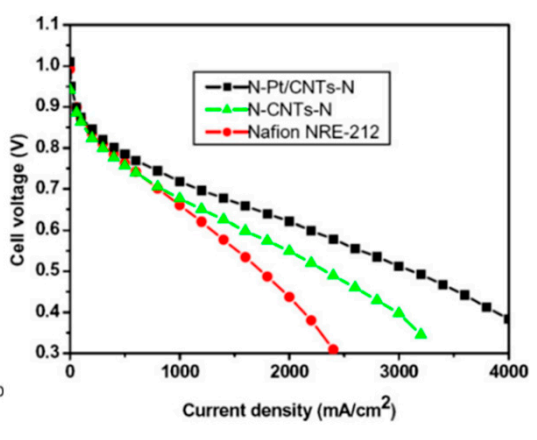

Figure 7. (a) I-V curves for plain and nanocomposite PEMs with a gradational $\mathrm{Pt}$ dispersion at $70{ }^{\circ} \mathrm{C}$ and (b) stability test of Pt/PFSA membrane at a constant output current density for $24 \mathrm{~h}$ (reprinted with permission from [87]); (c) I-V curves for plain PEM and Nafion incorporated with $\mathrm{Pt}$ and $\mathrm{Pt} / \mathrm{C}$ near the anode layer at $80^{\circ} \mathrm{C}$ and dry condition (reprinted with permission from [89]); (d) I-V curves for additive-free and three-layer nanocomposite Nafion with $\mathrm{Pt} / \mathrm{CNT}$ or $\mathrm{CNT}$ at $80^{\circ} \mathrm{C}$ and dry conditions (reprinted with permission from [91]).

Furthermore, in order to take advantage of the high surface area and mechanical stability of carbon-based additives without the risk of electronic short circuit, graphene oxide (GO) was introduced as a non-conductive material [93]. Besides, one can improve the IEC of GOs by functionalization, where the incorporation of GO functionalized by sulfonic acid groups in Nafion exhibited promising proton conductivity and water retention compared to additive-free PEM at low humidity condition [94]. However, their usage in self-humidifying PEMs was first investigated by Lee et al. [95]. They synthesized GO from graphite using Hummer's method, where an SEM image of GO sheets is indicated in Figure 8a. In the next step, Pt particles were deposited onto GO by a microwave treatment. Thus, oxygen groups in GO were inevitably removed, ensuing a chemical reduction reaction. Eventually, Pt-graphene $(\mathrm{Pt}-\mathrm{G})$ multilayer sheets were obtained. As indicated in Figure $8 \mathrm{~b}$, the average Pt particle size of $1.87 \mathrm{~nm}$ was reported, which manifests uniform distribution, although some agglomerations can be spotted. Basically, graphene sheets are likely to agglomerate as a result of Van der Waals interactions. Nanocomposite PEMs were prepared by solution casting, subsequent to mixing with Nafion solution. 
Nevertheless, the resulted support (graphene) is a highly electron-conductive and hydrophobic material that cannot suggest promising features for self-humidifying PEMs. As reported, Pt-G/Nafion failed to exhibit acceptable fuel cell performance at $80^{\circ} \mathrm{C}$ and in different humidity conditions, which can be explained by its poor water retention and electron loss within the electron conduction channels in the membrane. Having observed the outcome, Lee et al. added $\mathrm{SiO}_{2}$ to Pt-G/Nafion solution prior to casting in order to exploit its water retention properties [96]. The higher loading of $\mathrm{SiO}_{2}$ nanoparticles led to higher WU and proton conductivity. To be exact, the WU and proton conductivity values of $20 \%$ and $67 \mathrm{mS} \mathrm{cm}^{-1}$ were reported for a Pt-G/Nafion membrane with $1.5 \mathrm{wt} \% \mathrm{Pt}-\mathrm{G}$ incorporation, whereas these figures soared to $27 \%$ and $82.5 \mathrm{mS} \mathrm{cm}^{-1}$, subsequent to $3 \mathrm{wt} \% \mathrm{SiO}_{2}$ addition. While the $\mathrm{Pt}-\mathrm{G}$ and $\mathrm{SiO}_{2}$ loading varied between 0 and $3 \mathrm{wt} \%$, the best fuel cell performance in dry conditions was achieved after $1.5 \mathrm{wt} \% \mathrm{Pt}-\mathrm{G}$ and $1.5 \mathrm{wt} \% \mathrm{SiO}_{2}$ addition, and the polarization curves are presented in Figure 8c. It was argued that too many inorganic particles can block the ion conduction path and deteriorate the electrochemical performance. In contrast, PEMs OCV values increased with $\mathrm{SiO}_{2}$ content, no matter how much Pt-G was incorporated. Moreover, nanocomposite membranes showed brittle behavior in the tensile test, which is not favorable for PEFC application. Overall, the electron loss within the Pt-G network could be predicted, and long-term durability remained a challenge for this type of self-humidifying PEMs.
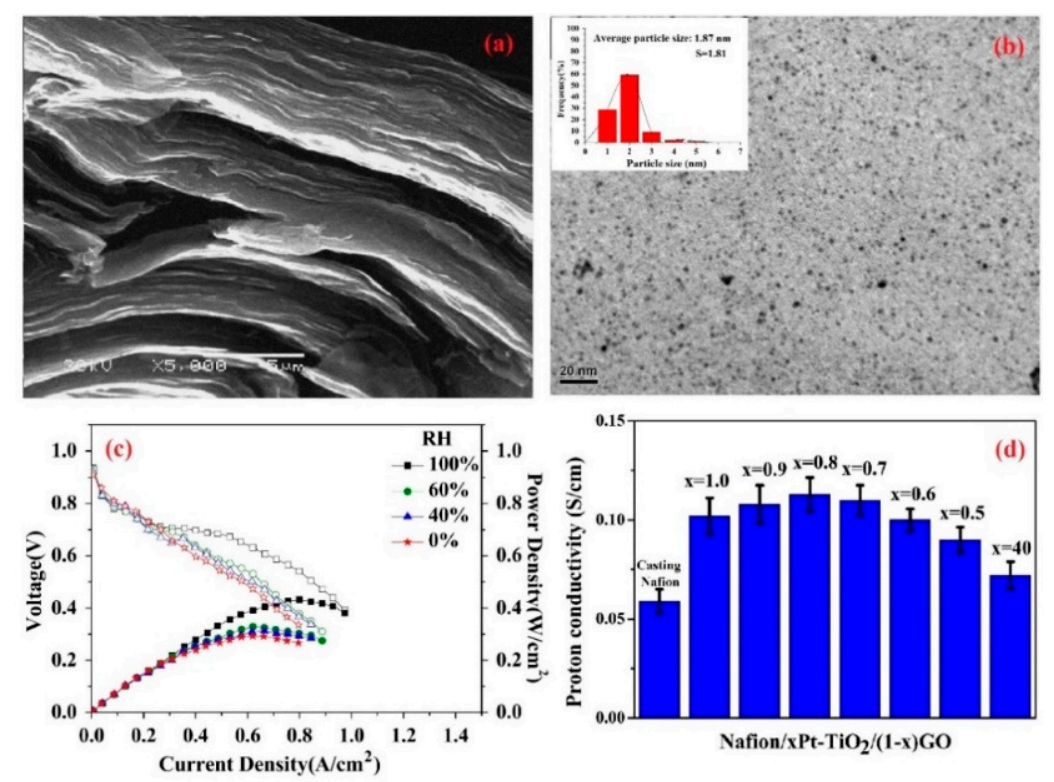

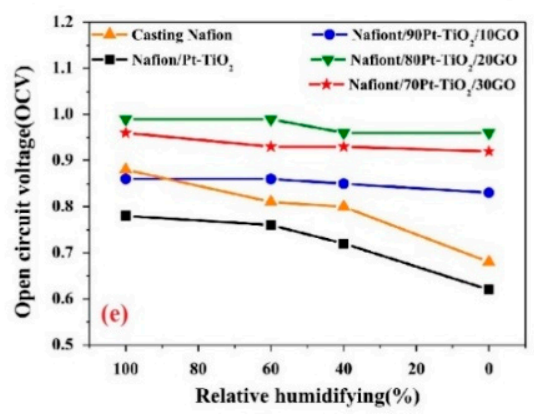

Figure 8. (a) SEM image of graphene oxide (GO) sheets (reprinted with permission from [95]); (b) TEM illustration of Pt-graphene with average Pt particle size of $1.87 \mathrm{~nm}$ and (c) I-V curves for $1.5 \mathrm{wt} \%$ $\mathrm{Pt}-\mathrm{G}$ and $1.5 \mathrm{wt} \% \mathrm{SiO}_{2}$ additives in a Nafion nanocomposite membrane at $80{ }^{\circ} \mathrm{C}$ and different relative humidity (RH) values (reprinted with permission from [96]); (d) proton conductivity and (e) open circuit voltage $(\mathrm{OCV})$ values for plain and nanocomposite $\mathrm{PEMs}$ containing $\mathrm{Pt}-\mathrm{TiO}_{2}$ and $\mathrm{GO}$ additives (reprinted with permission from [97]). 
Eventually, $\mathrm{Pt}-\mathrm{TiO}_{2} / \mathrm{GO} / \mathrm{Nafion}$ nanocomposite $\mathrm{PEM}$ appeared to overcome this issue, as proposed by Yang et al. [97]. To this end, $\mathrm{Pt}$ was impregnated onto commercial $\mathrm{TiO}_{2}$ nanoparticles and along with synthesized GO was added to the Nafion solution. Then, the solution casting method was utilized to prepare $x \mathrm{Pt}-\mathrm{TiO}_{2} /(1-\mathrm{x}) \mathrm{GO} / \mathrm{Nafion}$ membranes, where $\mathrm{x}$ varied from 0.4 to $1.0 \mathrm{wt} \%$. It was shown that $\mathrm{x}=0.8$ results in the highest IEC value, as this sample exhibited an improvement of about $13 \%$ compared to plain Nafion $\left(0.87 \mathrm{meq} \mathrm{g}^{-1}\right)$. Furthermore, as the contact angle measurements suggested, the PEM with $x=0.8$ showed more hydrophilicity $\left(53.2^{\circ}\right)$ than additive-free Nafion $\left(89.8^{\circ}\right)$. Thus, the highest proton conductivity was observed for this nanocomposite PEM, as reported in Figure 8d. While the incorporation of GO caused improved water retention properties, this value should be optimized to avoid proton conduction blockage. Not only did the $0.8 \mathrm{Pt}-\mathrm{TiO}_{2} / 0.2 \mathrm{GO} / \mathrm{Nafion} \mathrm{PEM}$ exhibit an excellent fuel cell performance at completely dry condition, but it also maintained high OCV at various RHs, as shown in Figure 8e. These data can showcase the capability of GO sheets in providing abundant catalytic sites for reactant recombination and consequently, the alleviation of performance deterioration at low humidification degrees.

A polymeric matrix due to its great compatibility with an ionomer can be employed to disperse the catalysts within the PEM as well. A self-assembly method was proposed in which uniformly dispersed Pt particles were stabilized with poly(diallyldimethylammonium chloride) (PDDA) and mounted onto a PTFE support $[98,99]$. Shichun et al. immersed a Nafion/PTFE membrane in a Pt-PDDA solution to prepare the self-humidifying PEM [98]. Given the dominant interaction between positively charged Pt-PDDA particles and negatively charged sulfonic acid groups within the ionomer, the possible electrical shorting can be prevented in this technique. The uniform dispersion after $36 \mathrm{~h}$ of self-assembly was proven by $\mathrm{Pt}$ mapping in their study [98]. Using the same technique, Liu et al. prepared Pt-PDDA/Nafion/PTFE membrane $(25 \mu \mathrm{m})$ and reported its stable output voltage after $12 \mathrm{~h}$ working under a constant load of $400 \mathrm{~mA} \mathrm{~cm}{ }^{-2}$ at $65^{\circ} \mathrm{C}$, whereas PTFE/Nafion exhibited a $0.23 \mathrm{~V}$ drop after this period. This observation can be interpreted as the successful suppression of permeated reactants. In addition, the self-humidifying PEM with Pt loading of only $1.7 \mu \mathrm{g} \mathrm{cm}^{-2}$ showed an improvement in power density of around $16 \%$ at dry condition, $65^{\circ} \mathrm{C}$, and $0.6 \mathrm{~V}$ [99].

Lastly, Table 1 presents a summary of studies regarding the different self-humidifying PEMs endowed with Pt nanoparticles as catalyst for internal water production. Furthermore, some key characteristics such as WU, proton conductivity, and maximum power density are reported for different membranes. It is worth mentioning that an OCV comparison between plain and nanocomposite membranes can demonstrate how efficiently reactant gases are combined within PEM to produce water.

Table 1. A summary of the main contributions about self-humidifying PEMs for PEFC application.

\begin{tabular}{|c|c|c|c|c|c|}
\hline Samples & $\begin{array}{l}\text { Thickness } \\
\quad(\mu \mathrm{m})\end{array}$ & $\begin{array}{c}\text { Proton } \\
\text { Conductivity/IEC }\end{array}$ & $\begin{array}{l}\text { WU } \\
(\%)\end{array}$ & $\begin{array}{c}\text { Max. Power } \\
\text { Density } \\
\left(\mathrm{W} \mathrm{cm}^{-2}\right)\end{array}$ & $\begin{array}{l}\text { OCV } \\
\text { (V) }\end{array}$ \\
\hline Plain Nafion [41] & 50 & - & $16.9\left(60^{\circ} \mathrm{C}\right)$ & - & 0.85 (dry) \\
\hline $\mathrm{Pt}-\mathrm{SiO}_{2} /$ Nafion [41] & 50 & - & $41.2\left(60^{\circ} \mathrm{C}\right)$ & - & 0.96 (dry) \\
\hline Nafion 212 [50] & 50 & - & $\begin{array}{c}21.08 \\
\left(60^{\circ} \mathrm{C}\right) \\
\end{array}$ & $\begin{array}{c}0.88 \\
\left(80^{\circ} \mathrm{C}, \mathrm{dry}\right)\end{array}$ & - \\
\hline $\begin{array}{l}\mathrm{Pt}-\mathrm{SiO}_{2} / \\
\text { Nafion/PTFE [50] }\end{array}$ & 25 & - & $\begin{array}{c}38.7 \\
\left(60^{\circ} \mathrm{C}\right) \\
\end{array}$ & $\begin{array}{c}1.29 \\
\left(80^{\circ} \mathrm{C}, \text { dry }\right)\end{array}$ & - \\
\hline Nafion/PTFE [51] & 20 & - & $\begin{array}{c}24.5 \\
\left(\approx 100^{\circ} \mathrm{C}\right)\end{array}$ & $\begin{array}{c}0.98 \\
\left(60^{\circ} \mathrm{C}, \text { dry }\right)\end{array}$ & 0.93 (dry) \\
\hline $\begin{array}{l}\mathrm{Pt}-\mathrm{SiO}_{2} / \mathrm{Nafion} / \mathrm{PTFE} \\
\text { (Multilayer) [51] }\end{array}$ & 20 & - & $\begin{array}{c}54.5 \\
\left(\approx 100^{\circ} \mathrm{C}\right)\end{array}$ & $\begin{array}{c}1.4 \\
\left(60^{\circ} \mathrm{C}, \mathrm{dry}\right)\end{array}$ & 1.032 (dry) \\
\hline SPEEK/PTFE [52] & 24 & $\begin{array}{l}8.5 \mathrm{mS} \mathrm{cm}^{-1} \\
\text { (dry) }\end{array}$ & $\begin{array}{c}24 \\
\left(60^{\circ} \mathrm{C}\right)\end{array}$ & $\begin{array}{c}0.33 \\
\left(60^{\circ} \mathrm{C}, \text { dry }\right)\end{array}$ & 0.94 (dry) \\
\hline
\end{tabular}


Table 1. Cont.

\begin{tabular}{|c|c|c|c|c|c|}
\hline Samples & $\begin{array}{l}\text { Thickness } \\
\qquad(\mu \mathrm{m})\end{array}$ & $\begin{array}{c}\text { Proton } \\
\text { Conductivity/IEC }\end{array}$ & $\begin{array}{l}\text { WU } \\
(\%)\end{array}$ & $\begin{array}{c}\text { Max. Power } \\
\text { Density } \\
\left(\mathrm{W} \mathrm{cm}^{-2}\right)\end{array}$ & $\begin{array}{l}\text { OCV } \\
\text { (V) }\end{array}$ \\
\hline $\begin{array}{l}\mathrm{Pt}-\mathrm{SiO}_{2} / \mathrm{SPEEK} / \mathrm{PTFE} \\
\text { (Multilayer) [52] }\end{array}$ & 24 & $\begin{array}{l}20 \mathrm{mS} \mathrm{cm}^{-1} \\
\quad \text { (dry) }\end{array}$ & $\begin{array}{c}31 \\
\left(60^{\circ} \mathrm{C}\right) \\
\end{array}$ & $\begin{array}{c}0.8 \\
\left(60^{\circ} \mathrm{C}, \mathrm{dry}\right)\end{array}$ & 0.98 (dry) \\
\hline $\mathrm{Pt}-\mathrm{TiO}_{2} /$ Nafion [53] & 50 & - & $37.9\left(60^{\circ} \mathrm{C}\right)$ & $\begin{array}{c}0.65\left(80^{\circ} \mathrm{C}\right. \\
\text { dry) }\end{array}$ & 0.96 (dry) \\
\hline Recast Nafion [54] & 40 & $0.91 \mathrm{meq} \mathrm{g}^{-1}$ & $\begin{array}{c}30.6 \\
\left(30^{\circ} \mathrm{C}\right) \\
\end{array}$ & $\begin{array}{c}0.14 \\
\left(50^{\circ} \mathrm{C}, \mathrm{dry}\right)\end{array}$ & 0.77 (dry) \\
\hline Pt-SA/Nafion [54] & 40 & $0.89 \mathrm{meq} \mathrm{g}^{-1}$ & $\begin{array}{c}42.1 \\
\left(30^{\circ} \mathrm{C}\right)\end{array}$ & $\begin{array}{c}0.91 \\
\left(50^{\circ} \mathrm{C} \text {, dry }\right)\end{array}$ & 0.87 (dry) \\
\hline $\begin{array}{l}0.22 \text { wt \% Pt-zeolite } \\
\text { HY/Nafion [58] }\end{array}$ & 50 & - & $\begin{array}{c}10.4 \\
\text { (ambient) }\end{array}$ & $\begin{array}{l}@ 0.6 \mathrm{~V} \approx 0.3 \\
\left(50{ }^{\circ} \mathrm{C}, \mathrm{dry}\right)\end{array}$ & $\begin{array}{c}0.95 \\
\left(50^{\circ} \mathrm{C}, \text { dry }\right)\end{array}$ \\
\hline $\begin{array}{l}0.65 \text { wt \% Pt-zeolite } \\
\text { HY/Nafion [58] }\end{array}$ & 50 & - & $\begin{array}{c}15.2 \\
\text { (ambient) }\end{array}$ & $\begin{array}{l}@ 0.6 \mathrm{~V} \approx 0.6 \\
\left(50^{\circ} \mathrm{C}, \text { dry }\right)\end{array}$ & $\begin{array}{c}0.98 \\
\left(50^{\circ} \mathrm{C}, \text { dry }\right)\end{array}$ \\
\hline $\begin{array}{l}1.5 \mathrm{wt} \% \text { Pt-zeolite } \\
\text { HY/Nafion [58] }\end{array}$ & 50 & - & $\begin{array}{c}38.6 \\
\text { (ambient) }\end{array}$ & $\begin{array}{l}@ 0.6 \mathrm{~V} \approx 0.45 \\
\left(50^{\circ} \mathrm{C}, \text { dry }\right)\end{array}$ & $\begin{array}{c}0.96 \\
\left(50^{\circ} \mathrm{C}, \mathrm{dry}\right)\end{array}$ \\
\hline Pure Nafion [59] & 60 & $\begin{array}{l}13.1 \mathrm{mS} \mathrm{cm}^{-1} \\
\left(25^{\circ} \mathrm{C} \text {, wet }\right)\end{array}$ & $\begin{array}{c}22.5 \\
\left(25^{\circ} \mathrm{C}\right) \\
\end{array}$ & $\begin{array}{c}\approx 0.5 \\
\left(60^{\circ} \mathrm{C}, \mathrm{dry}\right)\end{array}$ & 0.86 (dry) \\
\hline Pt-clay/Nafion [59] & 60 & $\begin{array}{l}11.1 \mathrm{mS} \mathrm{cm}^{-1} \\
\left(25^{\circ} \mathrm{C} \text {, wet }\right)\end{array}$ & $\begin{array}{c}23 \\
\left(25^{\circ} \mathrm{C}\right)\end{array}$ & $\begin{array}{c}\approx 0.94 \\
\left(60^{\circ} \mathrm{C}, \mathrm{dry}\right)\end{array}$ & 0.881 (dry) \\
\hline Pure Nafion [61] & 9 & $\begin{array}{c}38 \mathrm{mS} \mathrm{cm}{ }^{-1} \\
\left(60^{\circ} \mathrm{C}, 70 \% \mathrm{RH}\right)\end{array}$ & - & $\begin{array}{c}0.873 \\
\left(60^{\circ} \mathrm{C}, \mathrm{dry}\right)\end{array}$ & 0.587 (dry) \\
\hline Pt-LDHs/Nafion [61] & 9 & $\begin{array}{c}39 \mathrm{mS} \mathrm{cm}-1 \\
\left(60^{\circ} \mathrm{C}, 70 \% \mathrm{RH}\right)\end{array}$ & - & $\begin{array}{c}1.174 \\
\left(60^{\circ} \mathrm{C}, \mathrm{dry}\right)\end{array}$ & 0.705 (dry) \\
\hline Plain SPEEK [68] & 24 & $\begin{array}{c}13 \mathrm{mS} \mathrm{cm}-1 \\
\left(40^{\circ} \mathrm{C}, 100 \% \mathrm{RH}\right)\end{array}$ & $\begin{array}{c}16 \\
\left(40^{\circ} \mathrm{C}\right) \\
\end{array}$ & $\begin{array}{c}0.54 \\
\left(60^{\circ} \mathrm{C}, \mathrm{dry}\right)\end{array}$ & 0.96 (dry) \\
\hline Pt-SZ/SPEEK [68] & 24 & $\begin{array}{c}17 \mathrm{mS} \mathrm{cm}-1 \\
\left(40^{\circ} \mathrm{C}, 100 \% \mathrm{RH}\right)\end{array}$ & $\begin{array}{c}20 \\
\left(40^{\circ} \mathrm{C}\right) \\
\end{array}$ & $\begin{array}{c}0.95 \\
\left(60^{\circ} \mathrm{C}, \mathrm{dry}\right) \\
\end{array}$ & 1.015 (dry) \\
\hline $\mathrm{Pt}-\mathrm{Cs}_{2.5} / \mathrm{SPEEK}[77]$ & 24 & $\begin{array}{l}53 \mathrm{mS} \mathrm{cm}{ }^{-1} \\
\left(60^{\circ} \mathrm{C} \text {, wet }\right)\end{array}$ & $\begin{array}{c}30.6 \\
\left(60^{\circ} \mathrm{C}\right)\end{array}$ & $\begin{array}{c}1.14 \\
\left(60^{\circ} \mathrm{C}, \mathrm{dry}\right)\end{array}$ & 0.99 (dry) \\
\hline Pure SPEEK [80] & 43 & $1.82 \mathrm{meq} \mathrm{g}^{-1}$ & $\begin{array}{c}34.8 \\
\left(50^{\circ} \mathrm{C}\right)\end{array}$ & - & 0.831 (dry) \\
\hline $\mathrm{Pt}-\mathrm{Cs}_{2.5} / \mathrm{SPEEK}[80]$ & 45 & $1.96 \mathrm{meq} \mathrm{g}^{-1}$ & $\begin{array}{c}45.9 \\
\left(50^{\circ} \mathrm{C}\right)\end{array}$ & - & 1.156 (dry) \\
\hline Pt/Nafion/PTFE [89] & 35 & - & - & - & 0.897 (dry) \\
\hline Pt-C/Nafion/PTFE [89] & 35 & - & - & - & 0.932 (dry) \\
\hline Pt-C/Nafion(Double layer) [90] & 30 & - & - & $\begin{array}{c}\approx 0.5 \\
\left(60^{\circ} \mathrm{C}, \text { dry }\right)\end{array}$ & $\begin{array}{c}0.953 \\
\left(50^{\circ} \mathrm{C} \text {, wet }\right) \\
\end{array}$ \\
\hline $\begin{array}{l}\text { Pt-CNT/Nafion } \\
\text { (Multilayer) [91] }\end{array}$ & 25 & - & $\begin{array}{c}22.18 \\
\left(80^{\circ} \mathrm{C}\right)\end{array}$ & - & $\begin{array}{c}1.01 \\
\left(80^{\circ} \mathrm{C}, \text { dry }\right)\end{array}$ \\
\hline Pt-CNF/Nafion [92] & 25 & 0.9 meq g $^{-1}$ & $\begin{array}{c}25 \\
\left(80^{\circ} \mathrm{C}\right) \\
\end{array}$ & $\begin{array}{c}0.688 \\
\left(50^{\circ} \mathrm{C}, \text { dry }\right)\end{array}$ & $\begin{array}{c}\sim 0.73 \\
\left(50^{\circ} \mathrm{C}, \text { dry }\right)\end{array}$ \\
\hline $\begin{array}{l}\text { Sulfonated Pt-CNF/ } \\
\text { Nafion [92] }\end{array}$ & 25 & $1.12 \mathrm{meq} \mathrm{g}^{-1}$ & $\begin{array}{c}36 \\
\left(80^{\circ} \mathrm{C}\right) \\
\end{array}$ & $\begin{array}{c}0.921 \\
\left(50{ }^{\circ} \mathrm{C}, \mathrm{dry}\right)\end{array}$ & $\begin{array}{c}\sim 0.83 \\
\left(50^{\circ} \mathrm{C}, \text { dry }\right)\end{array}$ \\
\hline 0.5 wt \% Pt-G/Nafion [95] & - & $\begin{array}{c}97 \mathrm{mS} \mathrm{cm}^{-1} \\
\text { (ambient, wet) }\end{array}$ & $\begin{array}{c}31 \\
\text { (ambient) }\end{array}$ & $\begin{array}{c}\approx 0.2 \\
\left(80{ }^{\circ} \mathrm{C} \text { dry }\right)\end{array}$ & $\begin{array}{c}0.77 \\
\left(80^{\circ} \mathrm{C}, \text { dry }\right)\end{array}$ \\
\hline $3.0 \mathrm{wt} \%$ Pt-G/Nafon [95] & - & $\begin{array}{c}100 \mathrm{mS} \mathrm{cm}^{-1} \\
\text { (ambient, wet) }\end{array}$ & $\begin{array}{c}30 \\
\text { (ambient) }\end{array}$ & $\begin{array}{c}\approx 0.25 \\
\left(80^{\circ} \mathrm{C}, \mathrm{dry}\right)\end{array}$ & $\begin{array}{c}0.9 \\
\left(80^{\circ} \mathrm{C}, \text { dry }\right)\end{array}$ \\
\hline $4.5 \mathrm{wt} \% \mathrm{Pt}-\mathrm{G} /$ Nafion [95] & - & $\begin{array}{l}105 \mathrm{mS} \mathrm{cm}^{-1} \\
\text { (ambient, wet) }\end{array}$ & $\begin{array}{c}29 \\
\text { (ambient) }\end{array}$ & $\begin{array}{c}\approx 0.2 \\
\left(80{ }^{\circ} \mathrm{C}, \text { dry }\right)\end{array}$ & $\begin{array}{c}0.76 \\
\left(80^{\circ} \mathrm{C}, \mathrm{dry}\right)\end{array}$ \\
\hline
\end{tabular}


Table 1. Cont.

\begin{tabular}{|c|c|c|c|c|c|}
\hline Samples & $\begin{array}{l}\text { Thickness } \\
\qquad(\mu \mathrm{m})\end{array}$ & $\begin{array}{c}\text { Proton } \\
\text { Conductivity/IEC }\end{array}$ & $\begin{array}{l}\text { WU } \\
(\%)\end{array}$ & $\begin{array}{l}\text { Max. Power } \\
\text { Density } \\
\left(\mathrm{W} \mathrm{cm}^{-2}\right)\end{array}$ & $\begin{array}{l}\text { OCV } \\
\text { (V) }\end{array}$ \\
\hline $\begin{array}{l}3.0 \mathrm{wt} \% \mathrm{Pt}-\mathrm{G} / 1.5 \mathrm{wt} \% \\
\mathrm{SiO}_{2 /} \text { Nafion [96] }\end{array}$ & - & $\begin{array}{c}91 \mathrm{mS} \mathrm{cm}^{-1} \\
\text { (ambient, wet) }\end{array}$ & $\begin{array}{c}27 \\
\text { (ambient) }\end{array}$ & $\begin{array}{c}\approx 0.12 \\
\left(80^{\circ} \mathrm{C}, \mathrm{dry}\right)\end{array}$ & $\begin{array}{c}0.89 \\
\left(80^{\circ} \mathrm{C}, \text { dry }\right)\end{array}$ \\
\hline $\begin{array}{l}3.0 \mathrm{wt} \% \mathrm{Pt}-\mathrm{G} / 3.0 \mathrm{wt} \% \\
\mathrm{SiO}_{2 / \text { Nafion [96] }}\end{array}$ & - & $\begin{array}{c}92 \mathrm{mS} \mathrm{cm}^{-1} \\
\text { (ambient, wet) }\end{array}$ & $\begin{array}{c}30 \\
\text { (ambient) }\end{array}$ & $\begin{array}{c}\approx 0.13 \\
\left(80^{\circ} \mathrm{C}, \mathrm{dry}\right)\end{array}$ & $\begin{array}{c}0.96 \\
\left(80^{\circ} \mathrm{C}, \text { dry }\right)\end{array}$ \\
\hline Casting Nafion [97] & - & $\begin{array}{c}60 \mathrm{mS} \mathrm{cm}^{-1} \\
\text { (ambient, wet) }\end{array}$ & $\begin{array}{c}32.5 \\
\text { (ambient) }\end{array}$ & $\begin{array}{c}\approx 0.0 \\
\left(80^{\circ} \mathrm{C}, \text { dry }\right)\end{array}$ & $\begin{array}{c}0.68 \\
\left(80^{\circ} \mathrm{C}, \text { dry }\right)\end{array}$ \\
\hline $\begin{array}{l}0.7 \mathrm{Pt}-\mathrm{TiO}_{2} / 0.3 \\
\mathrm{GO} / \text { Nafion [97] }\end{array}$ & - & $\begin{array}{c}115 \mathrm{mS} \mathrm{cm}^{-1} \\
\text { (ambient, wet) }\end{array}$ & $\begin{array}{c}37.5 \\
\text { (ambient) }\end{array}$ & $\begin{array}{c}\approx 0.3 \\
\left(80^{\circ} \mathrm{C}, \mathrm{dry}\right)\end{array}$ & $\begin{array}{c}0.94 \\
\left(80^{\circ} \mathrm{C}, \text { dry }\right)\end{array}$ \\
\hline $\begin{array}{l}0.8 \mathrm{Pt}-\mathrm{TiO}_{2} / 0.2 \\
\mathrm{GO} / \text { Nafion [97] }\end{array}$ & - & $\begin{array}{c}118 \mathrm{mS} \mathrm{cm}^{-1} \\
\text { (ambient, wet) }\end{array}$ & $\begin{array}{c}37 \\
\text { (ambient) }\end{array}$ & $\begin{array}{c}\approx 0.5 \\
\left(80{ }^{\circ} \mathrm{C}, \text { dry }\right)\end{array}$ & $\begin{array}{c}0.97 \\
\left(80^{\circ} \mathrm{C}, \mathrm{dry}\right)\end{array}$ \\
\hline Recast Nafion [99] & 25 & $\begin{array}{l}122 \mathrm{mS} \mathrm{cm}^{-1} \\
\left(80^{\circ} \mathrm{C} \text {, wet }\right)\end{array}$ & $\begin{array}{c}25.2 \\
\left(80^{\circ} \mathrm{C}\right)\end{array}$ & - & $\approx 0.99$ (dry) \\
\hline $\begin{array}{l}\text { Pt-PDDA } \\
\text { /Nafion/PTFE [99] }\end{array}$ & 25 & $\begin{array}{l}74 \mathrm{mS} \mathrm{cm}^{-1} \\
\left(80^{\circ} \mathrm{C} \text {, wet }\right)\end{array}$ & $\begin{array}{c}16.3 \\
\left(80^{\circ} \mathrm{C}\right)\end{array}$ & - & $\approx 1.01$ (dry) \\
\hline
\end{tabular}

\section{Prevailing Challenges and Possible Remedies}

Notwithstanding the advances in the field of self-humidifying PEMs, there have always been challenges, and we will summarize the most crucial ones herein. Table 2 lists the possible problems associated with self-humidifying PEMs and remedies presented in the literature.

Table 2. Challenges and presented remedies in the field of self-humidifying PEMs.

\begin{tabular}{|c|c|c|}
\hline Challenges & Remedies & Ref. \\
\hline \multirow{3}{*}{$\begin{array}{l}\text { High ohmic resistance } \\
\text { (hygroscopic additives) }\end{array}$} & Smaller additives with higher surface area can be used. & [41] \\
\hline & $\begin{array}{l}\text { Hybrid of proton-conductive and hygroscopic materials can } \\
\text { be used. }\end{array}$ & {$[70]$} \\
\hline & Functionalization can provide more proton-conductive sites. & {$[72]$} \\
\hline $\begin{array}{l}\text { High ohmic resistance } \\
\text { (proton conductors) }\end{array}$ & $\begin{array}{l}\text { Either insufficient or excessive amount of additive/catalyst is } \\
\text { used. This amount should be optimized. }\end{array}$ & {$[80]$} \\
\hline High ohmic resistance & $\begin{array}{l}\text { In any case, thinner membranes can boost } \\
\text { proton conductivity. }\end{array}$ & [61] \\
\hline $\begin{array}{l}\text { Mechanical instability of } \\
\text { ultra-thin membranes }\end{array}$ & Can be reinforced with PTFE support. & {$[50]$} \\
\hline \multirow{2}{*}{$\begin{array}{l}\text { High gas cross-over rate and low } \\
\text { OCV value }\end{array}$} & $\begin{array}{l}\text { Multilayer structures can effectively suppress permeated } \\
\text { reactants. }\end{array}$ & [51] \\
\hline & $\begin{array}{l}\text { Uniform distribution of catalysts provides abundant } \\
\text { recombination active catalytic sites. }\end{array}$ & [97] \\
\hline $\begin{array}{l}\text { Agglomeration or migration } \\
\text { of additives }\end{array}$ & $\begin{array}{l}\text { Surface modification or the functionalization of additives } \\
\text { can solve this issue. }\end{array}$ & {$[60]$} \\
\hline Mechanical brittleness & $\begin{array}{l}\text { Better dispersion and compatibility with the polymer matrix } \\
\text { can improve the mechanical resilience of PEMs. }\end{array}$ & [81] \\
\hline \multirow{3}{*}{ Electron short circuit } & Multilayer approach can eliminate this problem. & [90] \\
\hline & Functionalization can solve the electron transfer issue. & [92] \\
\hline & $\begin{array}{l}\text { Pt particles can be stabilized by a polymeric matrix with } \\
\text { positive charge. }\end{array}$ & [99] \\
\hline
\end{tabular}


Table 2. Cont.

\begin{tabular}{lll}
\hline \multicolumn{1}{c}{ Challenges } & \multicolumn{1}{c}{ Remedies } & Ref. \\
\hline $\begin{array}{l}\text { Free radical-induced chemical } \\
\text { degradation in OCV test }\end{array}$ & $\begin{array}{l}\mathrm{Cs}_{2.5} \mathrm{H}_{0.5} \mathrm{PW}_{12} \mathrm{O}_{40} \text { scavenges } \mathrm{H}_{2} \mathrm{O}_{2} \text { and inhibits free } \\
\text { radical formation. }\end{array}$ & [83] \\
\hline $\begin{array}{l}\text { Anode-side dehydration at high } \\
\text { current densities }\end{array}$ & $\begin{array}{l}\text { A self-humidifying layer near the anode electrode can } \\
\text { prevent dehydration. } \\
\text { Use of thinner membranes can improve water } \\
\text { back-diffusion. }\end{array}$ & [90] \\
\hline
\end{tabular}

\section{Future Prospects of Self-Humidifying PEMs}

Despite the notable diversity of utilized fillers and supporting materials for self-humidifying PEMs, the polymeric matrix has not equally been improved, and the literature has mainly focused on PFSA and SPEEK membranes. In fact, the most recent and state of the art hydrocarbon-based PEMs, with meticulous phase separation, deserve more attention in this field. Furthermore, it is advisable to choose additives according to the type of PEM. In other words, metal oxides suggested water retention at high temperatures and dry conditions and might lead to the best outcome for PFSAs. On the other hand, one may notice that SPEEK demonstrated the best result with the addition of proton-conductor fillers that improved its Grotthuss mechanism. Hence, the fillers should be tailored and chosen based on the water absorption/desorption behavior and the dominant proton conduction mechanism of the employed polymeric matrix. Moreover, mechanical durability tests for these PEMs should be performed to confirm their reliability in the inevitable hydration and dehydration cycles during the harsh PEFC condition. Another concern is the amount of Pt incorporation within the self-humidifying PEMs. As the mainstream efforts in the field of PEFC indicate, Pt loading plays an important role in cost-reduction strategies. Hence, new preparation methods for developing cost-effective self-humidifying PEMs with low Pt loading should be embraced, albeit some existing self-humidifying PEMs are already utilizing quite low amounts of Pt catalyst.

\section{Conclusions}

This review paper investigated the advances and challenges of self-humidifying PEMs containing Pt nanoparticles for internal water production and other additives that are classified into three categories of inorganic (such as $\mathrm{SiO}_{2}, \mathrm{TiO}_{2}$, zeolites, and clays), proton-conductive (such as sulfated zirconia and HPAs), and carbon-based (such as CNT, graphene, and graphene oxide) materials. Ultra-thin self-humidifying PEMs (mostly $<50 \mu \mathrm{m}$ ) exhibited promising proton conductivity and fuel cell performance in dry conditions, given their ability to retain water obtaining from back-diffused water from the cathode and produced water within the membrane on the Pt surface. In addition, it has been shown that some additives such as HPAs can lower the percolation threshold, i.e., the required water content for proton conduction. Although the higher amount of gas cross-over was reported for thin nanocomposite PEMs, permeated reactants were only consumed to produce water and did not contribute to chemical degradation, nor mixed potential formation at the cathode layer, as high OCV values suggested. In addition, self-humidifying PEMs indicated acceptable mechanical properties, particularly those reinforced with PTFE support. Furthermore, the amount of catalyst loading is of paramount importance. High $\mathrm{Pt}$ loading may cause catalyst agglomeration, destructive radical formation, and the blockage of proton conduction paths. On the other hand, it can potentially increase the cost of PEFCs. Thus, an optimum Pt loading should be chosen.

Author Contributions: Conceptualization, S.H.M., M.J.P. and S.R.; Writing-Original Draft Preparation, S.H.M. and M.J.P.; Writing-Review \& Editing, S.H.M., M.J.P. and S.R.; Visualization, S.H.M. and M.J.P.; Supervision, M.J.P. and S.R. All authors have read and agreed to the published version of the manuscript.

Funding: This research received no external funding.

Conflicts of Interest: The authors declare no conflict of interest. 


\section{References}

1. York, R.; Bell, S.E. Energy transitions or additions?: Why a transition from fossil fuels requires more than the growth of renewable energy. Energy Res. Soc. Sci. 2019, 51, 40-43. [CrossRef]

2. Liddle, B.; Sadorsky, P. How much does increasing non-fossil fuels in electricity generation reduce carbon dioxide emissions? Appl. Energy 2017, 197, 212-221. [CrossRef]

3. Shindell, D.; Smith, C.J. Climate and air-quality benefits of a realistic phase-out of fossil fuels. Nature 2019, 573, 408-411. [CrossRef] [PubMed]

4. Andújar, J.M.; Segura, F. Fuel cells: History and updating. A walk along two centuries. Renew. Sustain. Energy Rev. 2009, 13, 2309-2322. [CrossRef]

5. Wieser, C. Novel polymer electrolyte membranes for automotive applications-requirements and benefits. Fuel Cells 2004, 4, 245-250. [CrossRef]

6. Ramadhani, F.; Hussain, M.A.; Mokhlis, H. A Comprehensive review and technical guideline for optimal design and operations of fuel cell-based cogeneration systems. Processes 2019, 7, 950. [CrossRef]

7. Peighambardoust, S.J.; Rowshanzamir, S.; Amjadi, M. Review of the proton exchange membranes for fuel cell applications. Int. J. Hydrogen Energy 2010, 35, 9349-9384. [CrossRef]

8. Luo, X.; Wang, J.; Dooner, M.; Clarke, J. Overview of current development in electrical energy storage technologies and the application potential in power system operation. Appl. Energy 2015, 137, 511-536. [CrossRef]

9. Hermann, A.; Chaudhuri, T.; Spagnol, P. Bipolar plates for PEM fuel cells: A review. Int. J. Hydrogen Energy 2005, 30, 1297-1302. [CrossRef]

10. O’hayre, R.; Cha, S.-W.; Colella, W.; Prinz, F.B. Fuel Cell Fundamentals; John Wiley \& Sons: Hoboken, NJ, USA, 2016.

11. Ogungbemi, E.; Ijaodola, O.; Khatib, F.; Wilberforce, T.; El Hassan, Z.; Thompson, J.; Ramadan, M.; Olabi, A. Fuel cell membranes-Pros and cons. Energy 2019, 172, 155-172. [CrossRef]

12. Henkensmeier, D.; Sui, P.; Wong, K.; Kjeang, E.; Knights, S.; Djilali, N. Copolymer synergistic coupling for chemical stability and improved gas barrier properties of a polymer electrolyte membrane for fuel cell applications. Int. J. Hydrogen Energy 2020, 45, 7059-7068.

13. Mench, M.M.; Kumbur, E.C.; Veziroglu, T.N. Polymer Electrolyte Fuel Cell Degradation; Academic Press: Pittsburgh, PA, USA, 2011.

14. Singh, R.; Sui, P.; Wong, K.; Kjeang, E.; Knights, S.; Djilali, N. Modeling the effect of chemical membrane degradation on PEMFC performance. J. Electrochem. Soc. 2018, 165, F3328-F3336. [CrossRef]

15. Luo, X.; Ghassemzadeh, L.; Holdcroft, S. Effect of free radical-induced degradation on water permeation through PFSA ionomer membranes. Int. J. Hydrogen Energy 2015, 40, 16714-16723. [CrossRef]

16. Karimi, A.; Mirfarsi, S.H.; Rowshanzamir, S.; Beyraghi, F.; Lester, D. Vicious cycle during chemical degradation of sulfonated aromatic proton exchange membranes in the fuel cell application. Int. J. Energy Res. 2020, 44, 8877-8891. [CrossRef]

17. Mirfarsi, S.H.; Karimi, A.; Rowshanzamir, S.; Parnian, M.J. Study of mechanical degradation of sulfonated poly (ether ether ketone) membrane using ex-situ hygrothermal cycles for polymer electrolyte fuel cell application. J. Power Sources 2018, 401, 73-84. [CrossRef]

18. Khorasany, R.M.H.; Kjeang, E.; Wang, G.G.; Rajapakse, R.K.N.D. Simulation of ionomer membrane fatigue under mechanical and hygrothermal loading conditions. J. Power Sources 2015, 279, 55-63. [CrossRef]

19. Dafalla, A.M.; Jiang, F. Stresses and their impacts on proton exchange membrane fuel cells: A review. Int. J. Hydrogen Energy 2018, 43, 2327-2348. [CrossRef]

20. Moghaddam, J.A.; Parnian, M.J.; Rowshanzamir, S. Preparation, characterization, and electrochemical properties investigation of recycled proton exchange membrane for fuel cell applications. Energy 2018, 161, 699-709. [CrossRef]

21. Parnian, M.J.; Rowshanzamir, S.; Moghaddam, J.A. Investigation of physicochemical and electrochemical properties of recast Nafion nanocomposite membranes using different loading of zirconia nanoparticles for proton exchange membrane fuel cell applications. Mater. Sci. Energy Technol. 2018, 1, 146-154. [CrossRef]

22. Najmi, A.A.; Rowshanzamir, S.; Parnian, M.J. Study of physicochemical characterization of potassium-doped Nafion117 membrane and performance evaluation of air-breathing fuel cell in different alkali-methanol solutions. Energy 2016, 113, 1090-1098. [CrossRef] 
23. Najmi, A.A.; Rowshanzamir, S.; Parnian, M.J. Investigation of $\mathrm{NaOH}$ concentration effect in injected fuel on the performance of passive direct methanol alkaline fuel cell with modified cation exchange membrane. Energy 2016, 94, 589-599. [CrossRef]

24. Whiston, M.M.; Azevedo, I.L.; Litster, S.; Whitefoot, K.S.; Samaras, C.; Whitacre, J.F. Expert assessments of the cost and expected future performance of proton exchange membrane fuel cells for vehicles. Proc. Natl. Acad. Sci. USA 2019, 116, 4899-4904. [CrossRef] [PubMed]

25. US Department of Energy. DOE Technical Targets for Polymer Electrolyte Membrane Fuel Cell Components. Available online: https://www.energy.gov/eere/fuelcells/doe-technical-targets-polymerelectrolyte-membrane-fuel-cell-components (accessed on 3 August 2020).

26. Parnian, M.J.; Rowshanzamir, S.; Gashoul, F. Comprehensive investigation of physicochemical and electrochemical properties of sulfonated poly (ether ether ketone) membranes with different degrees of sulfonation for proton exchange membrane fuel cell applications. Energy 2017, 125, 614-628. [CrossRef]

27. Parnian, M.J.; Gashoul, F.; Rowshanzamir, S. Studies on the SPEEK membrane with low degree of sulfonation as a stable proton exchange membrane for fuel cell applications. Iran. J. Hydrog. Fuel Cell 2017, 3, 221-232.

28. Beyraghi, F.; Mirfarsi, S.H.; Rowshanzamir, S.; Karimi, A.; Parnian, M.J. Optimal thermal treatment conditions for durability improvement of highly sulfonated poly (ether ether ketone) membrane for polymer electrolyte fuel cell applications. Int. J. Hydrogen Energy 2020, 45, 13441-13458. [CrossRef]

29. Gashoul, F.; Parnian, M.J.; Rowshanzamir, S. A new study on improving the physicochemical and electrochemical properties of SPEEK nanocomposite membranes for medium temperature proton exchange membrane fuel cells using different loading of zirconium oxide nanoparticles. Int. J. Hydrogen Energy 2017, 42, 590-602. [CrossRef]

30. Parnian, M.J.; Rowshanzamir, S.; Prasad, A.K.; Advani, S.G. Effect of ceria loading on performance and durability of sulfonated poly (ether ether ketone) nanocomposite membranes for proton exchange membrane fuel cell applications. J. Membr. Sci. 2018, 565, 342-357. [CrossRef]

31. Parnian, M.J.; Rowshanzamir, S.; Prasad, A.K.; Advani, S.G. High durability sulfonated poly (ether ether ketone)-ceria nanocomposite membranes for proton exchange membrane fuel cell applications. J. Membr. Sci. 2018, 556, 12-22. [CrossRef]

32. Karimi, A.; Kalfati, M.S.; Rowshanzamir, S. Investigation, modeling, and optimization of parameters affecting sulfonated polyether ether ketone membrane-electrode assembly. Int. J. Hydrogen Energy 2019, 44, 1096-1109. [CrossRef]

33. Jiao, K.; Li, X. Water transport in polymer electrolyte membrane fuel cells. Prog. Energy Combust. Sci. 2011, 37, 221-291. [CrossRef]

34. Unlu, M.; Zhou, J.; Kohl, P.A. Hybrid anion and proton exchange membrane fuel cells. J. Phys. Chem. C 2009, 113, 11416-11423. [CrossRef]

35. Peng, S.; Xu, X.; Lu, S.; Sui, P.-C.; Djilali, N.; Xiang, Y. A self-humidifying acidic-alkaline bipolar membrane fuel cell. J. Power Sources 2015, 299, 273-279. [CrossRef]

36. Manohar, M.; Kim, D. Advantageous of hybrid fuel cell operation under self-humidification for energy efficient bipolar membrane. ACS Sustain. Chem. Eng. 2019, 7, 16493-16500. [CrossRef]

37. Fan, C.; Wu, H.; Li, Y.; Shi, B.; He, X.; Qiu, M.; Mao, X.; Jiang, Z. Incorporating self-anchored phosphotungstic acid@ triazole-functionalized covalent organic framework into sulfonated poly (ether ether ketone) for enhanced proton conductivity. Solid State Ion. 2020, 349, 115316. [CrossRef]

38. Jin, J.; Zhao, J.; Shen, S.; Yu, J.; Cheng, S.; Pan, B.; Che, Q. Constructing anhydrous proton exchange membranes based on cadmium telluride nanocrystal-doped sulfonated poly (ether ether ketone)/polyurethane composites. Nanotechnology 2020, 31, 205707. [CrossRef] [PubMed]

39. Sun, S.; Ling, L.; Xiong, Y.; Zhang, Y.; Li, Z. Trifluoromethanesulfonimide-based hygroscopic semi-interpenetrating polymer network for enhanced proton conductivity of nafion-based proton exchange membranes at low humidity. J. Membr. Sci. 2020, 612, 118339. [CrossRef]

40. Park, C.H.; Lee, S.Y.; Hwang, D.S.; Shin, D.W.; Cho, D.H.; Lee, K.H.; Kim, T.-W.; Kim, T.-W.; Lee, M.; Kim, D.-S. Nanocrack-regulated self-humidifying membranes. Nature 2016, 532, 480-483. [CrossRef]

41. Watanabe, M.; Uchida, H.; Seki, Y.; Emori, M.; Stonehart, P. Self-humidifying polymer electrolyte membranes for fuel cells. J. Electrochem. Soc. 1996, 143, 3847. [CrossRef]

42. Yoshida, T.; Kojima, K. Toyota MIRAI fuel cell vehicle and progress toward a future hydrogen society. Electrochem. Soc. Interface 2015, 24, 45. [CrossRef] 
43. Su, H.; Xu, L.; Zhu, H.; Wu, Y.; Yang, L.; Liao, S.; Song, H.; Liang, Z.; Birss, V. Self-humidification of a PEM fuel cell using a novel Pt/SiO2/C anode catalyst. Int. J. Hydrogen Energy 2010, 35, 7874-7880. [CrossRef]

44. Zheng, L.; Zeng, Q.; Liao, S.; Zeng, J. Highly performed non-humidification membrane electrode assembly prepared with binary $\mathrm{RuO} 2-\mathrm{SiO} 2$ oxide supported Pt catalysts as anode. Int. J. Hydrog. Energy 2012, 37, 13103-13109. [CrossRef]

45. Rahnavard, A.; Rowshanzamir, S.; Parnian, M.J.; Amirkhanlou, G.R. The effect of sulfonated poly (ether ether ketone) as the electrode ionomer for self-humidifying nanocomposite proton exchange membrane fuel cells. Energy 2015, 82, 746-757. [CrossRef]

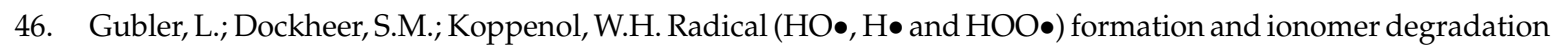
in polymer electrolyte fuel cells. J. Electrochem. Soc. 2011, 158, B755-B769. [CrossRef]

47. Amjadi, M.; Rowshanzamir, S.; Peighambardoust, S.; Hosseini, M.; Eikani, M. Investigation of physical properties and cell performance of Nafion/TiO2 nanocomposite membranes for high temperature PEM fuel cells. Int. J. Hydrogen Energy 2010, 35, 9252-9260. [CrossRef]

48. Amjadi, M.; Rowshanzamir, S.; Peighambardoust, S.; Sedghi, S. Preparation, characterization and cell performance of durable nafion/SiO2 hybrid membrane for high-temperature polymeric fuel cells. J. Power Sources 2012, 210, 350-357. [CrossRef]

49. Hagihara, H.; Uchida, H.; Watanabe, M. Preparation of highly dispersed $\mathrm{SiO} 2$ and Pt particles in Nafion ${ }^{\circledR}$ 112 for self-humidifying electrolyte membranes in fuel cells. Electrochim. Acta 2006, 51, 3979-3985. [CrossRef]

50. Wang, L.; Xing, D.; Liu, Y.; Cai, Y.; Shao, Z.-G.; Zhai, Y.; Zhong, H.; Yi, B.; Zhang, H. Pt/SiO2 catalyst as an addition to Nafion/PTFE self-humidifying composite membrane. J. Power Sources 2006, 161, 61-67. [CrossRef]

51. Zhu, X.; Zhang, H.; Zhang, Y.; Liang, Y.; Wang, X.; Yi, B. An ultrathin self-humidifying membrane for PEM fuel cell application: Fabrication, characterization, and experimental analysis. J. Phys. Chem. B 2006, 110, 14240-14248. [CrossRef]

52. Zhang, Y.; Zhang, H.; Zhu, X.; Gang, L.; Bi, C.; Liang, Y. Fabrication and characterization of a PTFE-reinforced integral composite membrane for self-humidifying PEMFC. J. Power Sources 2007, 165, 786-792. [CrossRef]

53. Watanabe, M.; Uchida, H.; Emori, M. Polymer electrolyte membranes incorporated with nanometer-size particles of Pt and/or metal-oxides: Experimental analysis of the self-humidification and suppression of gas-crossover in fuel cells. J. Phys. Chem. B 1998, 102, 3129-3137. [CrossRef]

54. Tsai, C.-H.; Yang, F.-L.; Chang, C.-H.; Chen-Yang, Y.W. Microwave-assisted synthesis of silica aerogel supported pt nanoparticles for self-humidifying proton exchange membrane fuel cell. Int. J. Hydrogen Energy 2012, 37, 7669-7676. [CrossRef]

55. Li, J.; Tang, H.; Wang, Z.; Pan, M. Microstructure evolution of Nafion/silica membrane under humidity conditions. J. Power Sources 2013, 234, 333-339. [CrossRef]

56. Han, W.; Kwan, S.M.; Yeung, K.L. Zeolite applications in fuel cells: Water management and proton conductivity. Chem. Eng. J. 2012, 187, 367-371. [CrossRef]

57. Nicotera, I.; Enotiadis, A.; Angjeli, K.; Coppola, L.; Gournis, D. Evaluation of smectite clays as nanofillers for the synthesis of nanocomposite polymer electrolytes for fuel cell applications. Int. J. Hydrogen Energy 2012, 37, 6236-6245. [CrossRef]

58. Son, D.-H.; Sharma, R.K.; Shul, Y.-G.; Kim, H. Preparation of Pt/zeolite-Nafion composite membranes for self-humidifying polymer electrolyte fuel cells. J. Power Sources 2007, 165, 733-738. [CrossRef]

59. Zhang, W.; Li, M.K.S.; Yue, P.-L.; Gao, P. Exfoliated Pt-clay/Nafion nanocomposite membrane for self-humidifying polymer electrolyte fuel cells. Langmuir 2008, 24, 2663-2670. [CrossRef]

60. Narayanamoorthy, B.; Balaji, S. Physicochemical characterization of amino functionalized synthetic clay/Nafion nanocomposite film with embedded platinum nanoparticles for PEM fuel cells. Appl. Clay Sci. 2015, 104, 66-73. [CrossRef]

61. Wang, R.; Zhang, W.; He, G.; Gao, P. Controlling fuel crossover and hydration in ultra-thin proton exchange membrane-based fuel cells using Pt-nanosheet catalysts. J. Mater. Chem. A 2014, 2, 16416-16423. [CrossRef]

62. Lee, H.-K.; Seepana, M.M.; Shukla, A. A study on self-humidifying PEMFC using Pt-ZrP-Nafion composite membrane. Electrochim. Acta 2004, 50, 761-768. [CrossRef]

63. Pandey, J.; Seepana, M.M.; Shukla, A. Zirconium phosphate based proton conducting membrane for DMFC application. Int. J. Hydrogen Energy 2015, 40, 9410-9421. [CrossRef]

64. Hara, S.; Miyayama, M. Proton conductivity of superacidic sulfated zirconia. Solid State Ion. 2004, 168, 111-116. [CrossRef] 
65. Navarra, M.; Abbati, C.; Scrosati, B. Properties and fuel cell performance of a Nafion-based, sulfated zirconia-added, composite membrane. J. Power Sources 2008, 183, 109-113. [CrossRef]

66. Mossayebi, Z.; Parnian, M.J.; Rowshanzamir, S. Effect of the sulfated zirconia nanostructure characteristics on physicochemical and electrochemical properties of SPEEK nanocomposite membranes for PEM fuel cell applications. Macromol. Mater. Eng. 2018, 303. [CrossRef]

67. Mossayebi, Z.; Saririchi, T.; Rowshanzamir, S.; Parnian, M.J. Investigation and optimization of physicochemical properties of sulfated zirconia/sulfonated poly (ether ether ketone) nanocomposite membranes for medium temperature proton exchange membrane fuel cells. Int. J. Hydrog. Energy 2016, 41, 12293-12306. [CrossRef]

68. Zhang, Y.; Zhang, H.; Zhai, Y.; Zhu, X.; Bi, C. Investigation of self-humidifying membranes based on sulfonated poly (ether ether ketone) hybrid with sulfated zirconia supported Pt catalyst for fuel cell applications. J. Power Sources 2007, 168, 323-329. [CrossRef]

69. Zhang, Y.; Zhang, H.; Zhu, X.; Bi, C. Promotion of PEM self-humidifying effect by nanometer-sized sulfated zirconia-supported Pt catalyst hybrid with sulfonated poly (ether ether ketone). J. Phys. Chem. B 2007, 111, 6391-6399. [CrossRef]

70. Bi, C.; Zhang, H.; Zhang, Y.; Zhu, X.; Ma, Y.; Dai, H.; Xiao, S. Fabrication and investigation of SiO2 supported sulfated zirconia/Nafion ${ }^{\circledR}$ self-humidifying membrane for proton exchange membrane fuel cell applications. J. Power Sources 2008, 184, 197-203. [CrossRef]

71. Kumar, G.G.; Kim, A.; Nahm, K.S.; Elizabeth, R. Nafion membranes modified with silica sulfuric acid for the elevated temperature and lower humidity operation of PEMFC. Int. J. Hydrogen Energy 2009, 34, 9788-9794. [CrossRef]

72. Yang, H.; Cho, S.; Kim, W. The preparation of self-humidifying Nafion/various Pt-containing $\mathrm{SiO}_{2}$ composite membranes and their application in PEMFC. J. Membr. Sci. 2012, 421, 318-326. [CrossRef]

73. Yang, H.; Lee, D.; Park, S.; Kim, W. Preparation of Nafion/various Pt-containing SiO2 composite membranes sulfonated via different sources of sulfonic group and their application in self-humidifying PEMFC. J. Membr. Sci. 2013, 443, 210-218. [CrossRef]

74. Kourasi, M.; Wills, R.; Shah, A.; Walsh, F. Heteropolyacids for fuel cell applications. Electrochim. Acta 2014, 127, 454-466. [CrossRef]

75. Lee, C.; Na, H.; Jeon, Y.; Hwang, H.J.; Kim, H.-J.; Mochida, I.; Yoon, S.-H.; Park, J.-I.; Shul, Y.-G. Poly (ether imide) nanofibrous web composite membrane with $\mathrm{SiO} 2 /$ heteropolyacid ionomer for durable and high-temperature polymer electrolyte membrane (PEM) fuel cells. J. Ind. Eng. Chem. 2019, 74, 7-13. [CrossRef]

76. Amirinejad, M.; Madaeni, S.S.; Rafiee, E.; Amirinejad, S. Cesium hydrogen salt of heteropolyacids/Nafion nanocomposite membranes for proton exchange membrane fuel cells. J. Membr. Sci. 2011, 377, 89-98. [CrossRef]

77. Zhang, Y.; Zhang, H.; Bi, C.; Zhu, X. An inorganic/organic self-humidifying composite membranes for proton exchange membrane fuel cell application. Electrochim. Acta 2008, 53, 4096-4103. [CrossRef]

78. Wu, X.; He, G.; Li, X.; Nie, F.; Yan, X.; Yu, L.; Benziger, J. Improving proton conductivity of sulfonated poly (ether ether ketone) proton exchange membranes at low humidity by semi-interpenetrating polymer networks preparation. J. Power Sources 2014, 246, 482-490. [CrossRef]

79. Akbari, S.; Mosavian, M.T.H.; Moosavi, F.; Ahmadpour, A. Does the addition of a heteropoly acid change the water percolation threshold of PFSA membranes? Phys. Chem. Chem. Phys. 2019, 21, 25080-25089. [CrossRef]

80. Peighambardoust, S.; Rowshanzamir, S.; Hosseini, M.; Yazdanpour, M. Self-humidifying nanocomposite membranes based on sulfonated poly (ether ether ketone) and heteropolyacid supported Pt catalyst for fuel cells. Int. J. Hydrogen Energy 2011, 36, 10940-10957. [CrossRef]

81. Rowshanzamir, S.; Peighambardoust, S.J.; Parnian, M.J.; Amirkhanlou, G.R.; Rahnavard, A. Effect of Pt-Cs2. 5H0. 5PW12O40 catalyst addition on durability of self-humidifying nanocomposite membranes based on sulfonated poly (ether ether ketone) for proton exchange membrane fuel cell applications. Int. J. Hydrog. Energy 2015, 40, 549-560. [CrossRef]

82. Chen, C.; Fuller, T.F. Modeling of H2O2 formation in PEMFCs. Electrochim. Acta 2009, 54, $3984-3995$. [CrossRef]

83. Wang, L.; Yi, B.; Zhang, H.; Xing, D. Cs2. 5H0. 5PWO40/SiO2 as addition self-humidifying composite membrane for proton exchange membrane fuel cells. Electrochim. Acta 2007, 52, 5479-5483. [CrossRef] 
84. Sayadi, P.; Rowshanzamir, S.; Parnian, M.J. Study of hydrogen crossover and proton conductivity of self-humidifying nanocomposite proton exchange membrane based on sulfonated poly (ether ether ketone). Energy 2016, 94, 292-303. [CrossRef]

85. Gattia, D.M.; Antisari, M.V.; Giorgi, L.; Marazzi, R.; Piscopiello, E.; Montone, A.; Bellitto, S.; Licoccia, S.; Traversa, E. Study of different nanostructured carbon supports for fuel cell catalysts. J. Power Sources 2009, 194, 243-251. [CrossRef]

86. Kwak, S.-H.; Yang, T.-H.; Kim, C.-S.; Yoon, K.H. The effect of platinum loading in the self-humidifying polymer electrolyte membrane on water uptake. J. Power Sources 2003, 118, 200-204. [CrossRef]

87. Wang, C.; Liu, Z.; Mao, Z.; Xu, J.; Ge, K. Preparation and evaluation of a novel self-humidifying Pt/PFSA composite membrane for PEM fuel cell. Chem. Eng. J. 2005, 112, 87-91. [CrossRef]

88. Liu, Z.; Yang, Y.; Lü, W.; Wang, C.; Chen, M.; Mao, Z. Durability test of PEMFC with Pt-PFSA composite membrane. Int. J. Hydrogen Energy 2012, 37, 956-960. [CrossRef]

89. Liu, F.; Yi, B.; Xing, D.; Yu, J.; Hou, Z.; Fu, Y. Development of novel self-humidifying composite membranes for fuel cells. J. Power Sources 2003, 124, 81-89. [CrossRef]

90. Yang, B.; Fu, Y.; Manthiram, A. Operation of thin Nafion-based self-humidifying membranes in proton exchange membrane fuel cells with dry $\mathrm{H} 2$ and O2. J. Power Sources 2005, 139, 170-175. [CrossRef]

91. Liu, Y.-H.; Yi, B.; Shao, Z.-G.; Wang, L.; Xing, D.; Zhang, H. Pt/CNTs-Nafion reinforced and self-humidifying composite membrane for PEMFC applications. J. Power Sources 2007, 163, 807-813. [CrossRef]

92. Hung, T.; Liao, S.; Li, C.; Chen-Yang, Y. Effect of sulfonated carbon nanofiber-supported Pt on performance of Nafion ${ }^{\circledR}$-based self-humidifying composite membrane for proton exchange membrane fuel cell. J. Power Sources 2011, 196, 126-132. [CrossRef]

93. Bayer, T.; Bishop, S.; Nishihara, M.; Sasaki, K.; Lyth, S.M. Characterization of a graphene oxide membrane fuel cell. J. Power Sources 2014, 272, 239-247. [CrossRef]

94. Zarrin, H.; Higgins, D.; Jun, Y.; Chen, Z.; Fowler, M. Functionalized graphene oxide nanocomposite membrane for low humidity and high temperature proton exchange membrane fuel cells. J. Phys. Chem. C 2011, 115, 20774-20781. [CrossRef]

95. Lee, D.; Yang, H.; Park, S.; Kim, W. Nafion/graphene oxide composite membranes for low humidifying polymer electrolyte membrane fuel cell. J. Membr. Sci. 2014, 452, 20-28. [CrossRef]

96. Lee, D.; Yang, H.; Park, S.; Park, K.; Kim, W. Self-humidifying Pt-graphene/SiO2 composite membrane for polymer electrolyte membrane fuel cell. J. Membr. Sci. 2015, 474, 254-262. [CrossRef]

97. Yang, H.; Lee, W.; Choi, B.; Kim, W. Preparation of Nafion/Pt-containing TiO2/graphene oxide composite membranes for self-humidifying proton exchange membrane fuel cell. J. Membr. Sci. 2016, 504, $20-28$. [CrossRef]

98. Shichun, M.; Xiaoen, W.; Haolin, T.; Peigang, L.; Ming, L.; Mu, P.; RunZhang, Y. A self-humidifying composite membrane with self-assembled Pt nanoparticles for polymer electrolyte membrane fuel cells. J. Electrochem. Soc. 2006, 153, A1868. [CrossRef]

99. Liu, Y.; Nguyen, T.; Kristian, N.; Yu, Y.; Wang, X. Reinforced and self-humidifying composite membrane for fuel cell applications. J. Membr. Sci. 2009, 330, 357-362. [CrossRef]

(C) 2020 by the authors. Licensee MDPI, Basel, Switzerland. This article is an open access article distributed under the terms and conditions of the Creative Commons Attribution (CC BY) license (http://creativecommons.org/licenses/by/4.0/). 